\title{
British Columbia OfFShORE OIL ANd Gas LAW
}

\author{
Al Hudec AND VAN PENICK*
}

This article addresses the current debate over lifting a thirty-five year moratorium on offshore resource development in British Columbia. It describes the three primary offshore basins and the history of the various moratoriums, as well as the current legal backdrop under which development could occur. The authors review unique jurisdictional, Aboriginal and environmental considerations relating to the west coast, and conclude that the east coast regulatory regime provides a useful regulatory template for the west coast, appropriately updated for technological changes in the offshore industry and changes in regulatory philosophies since the 1980s.
Cet article aborde le débat actuel sur la levée du moratoire de trente-cinq ans sur le développement des ressources en Colombie-Britannique. L'auteur décrit les trois bassins littoraux, l'histoire des divers moratoires et le contexte juridique actuel dans lequel le développement pourrait avoir lieu. Les auteurs examinent les considérations relatives à la compétence, aux Autochtones et à l'environnement en ce qui concerne la côte ouest et en arrivent à la conclusion que le régime de réglementation de la côte est représente un modèle réglementaire utile pour la côte ouest une fois mis à jour pour tenir compte des changements technologiques dans ce secteur d'activité et des changements de philosophie réglementaire qui ont eu lieu depuis les années 1980.

\section{TABLE OF CONTENTS}

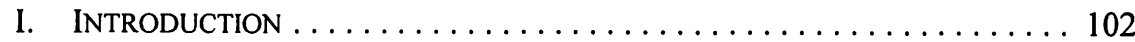

II. BRITISH COLUMBIA'S OFFSHORE HYDROCARBON BASINS $\ldots \ldots \ldots \ldots 103$

III. THE HISTORY OF BRITISH COLUMBIA OFFSHORE EXPLORATION AND THE MORATORIUMS $\ldots \ldots \ldots \ldots \ldots 105$

IV. PRIOR TECHNICAL, ENVIRONMENTAL

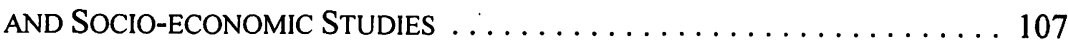

V. SOURCES OF LAW APPLICABLE TO THE BRITISH COLUMBIA OFFSHORE AREA . . . . . . . . . . . . . . . 108

A. CUSTOMARY INTERNATIONAL LAW AND INTERNATIONAL TREATIES ..................... 109

B. FEderal AND PRovincial LEGISLATION $\ldots \ldots \ldots \ldots \ldots \ldots \ldots$

C. JUDICIAL DECISIONS GOVERNING THE BRITISH COLUMBIA OFFSHORE ................ 111

VI. The Aboriginal Consultative Process $\ldots \ldots \ldots \ldots \ldots \ldots \ldots \ldots$

VII. CO-ORDINATED FEDERAL-PROVINCIAL

ENVIRONMENT REVIEW AND ASSESSMENT . . . . . . . . . . . . . . 117

A. ENVIRONMENT IMPACTS OF
OFFSHORE OIL AND GAS ACTIVITIES $\ldots \ldots \ldots \ldots \ldots \ldots \ldots \ldots \ldots \ldots$

B. COMBINED FEDERAL-PROVINCIAL OFFSHORE

ENVIRONMENTAL REVIEW AND ASSESSMENT $\ldots \ldots \ldots \ldots \ldots 120$

VIII. A PACIFIC ACCORD - ADAPTING THE

EAST COAST EXPERIENCES . . . . . . . . . . . . . . . . . 122

A. BACKGROUND ON THE EAST COAST

REGULATORY REGIMES ...................... 124

The authors are, respectively, partners at Davis \& Company in Vancouver, British Columbia and McInnes Cooper in Halifax, Nova Scotia. Both are directors of the Canadian Petroleum Law Foundation. The views expressed in this article do not necessarily reflect the views of their firms. 
B. REgUlATORY FleXIBILITY AND ACCOUNTABILITY $\ldots \ldots \ldots \ldots 126$

C. REVENUE- VERSUS BENEFITS-BASEd REGULATION . . . . . . . . 126

D. PERFORMANCE-BASED VERSUS

PREsCRIPTIVE REgUlation . . . . . . . . . . . . . . . . . . . . . . . . . 134

E. Royalties and ReVEnUE SHARING $\ldots \ldots \ldots \ldots \ldots \ldots \ldots \ldots$

F. SIGNIFICANT DISCOVERY DEFINITION $\ldots \ldots \ldots \ldots \ldots \ldots \ldots \ldots 151$

G. REGISTRY SYSTEM . . . . . . . . . . . . . . . . . . . . . . 153

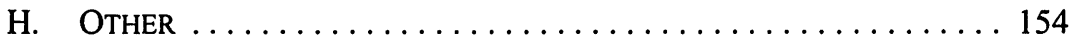

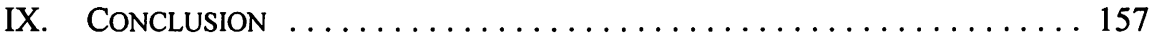

\section{INTRODUCTION}

Lifting the moratorium on British Columbia offshore oil and gas activity, which has been in place for the last thirty-five years, is again under active consideration. Before industry proponents emerge with an active interest in commencing seismic and other exploration activity on the west coast, the provincial and federal governments must together establish an integrated regulatory framework for offshore oil and gas activity (probably through the negotiation of a Pacific Accord) that provides industry with sufficient certainty to assess the financial rewards, as well as the political and regulatory risks, of proceeding with exploration and development activities.

This, in turn, requires satisfaction of at least three preconditions. First, Canada and British Columbia must settle jurisdictional issues; second, a consultative process must be established for Aboriginal interests that deals, with sufficient certainty, with ownership, management and benefit sharing; and third, a co-ordinated federal-provincial process must be implemented dealing with environmental review and assessment.

This article reviews the history of offshore oil and gas activity on the west coast and the moratoriums, judicial decisions pertaining to jurisdictional issues, and studies addressing the scientific, technical and environmental issues associated with west coast offshore oil and gas activities. ${ }^{1}$ It then goes beyond this analysis to present for the first time a discussion, based in part on the east coast experience, of the alternative regulatory regimes which might sensibly be applied to govern offshore activity on the west coast.

1 There have been several conferences dealing with west coast offshore oil and gas issues in recent years. In 1996, the Canadian Ocean Frontier Initiative Conference in Prince Rupert, B.C., investigated offshore oil and gas potential and lifting of the moratorium. In October 2000, the Maritime Awards Society of Canada organized an informal meeting of senior B.C. and federal government officials, academics and other specialists to review the knowledge available on offshore hydrocarbon development in light of current technologies. See also Exploring the Future of Offshore Oil and Gas Development in BC: Lessons from the Atlantic, a conference held at Simon Fraser University in September 2000, online: Simon Fraser University <www.sfu.ca/cstudies/science/oilgas>; D.M. Johnston \& E.N. Hildebrand, eds., B.C. Offshore Hydrocarbon Development: Issues and Prospects: A Background Report, prepared by the Maritime Awards Society of Canada (March 2001), online: University of Victoria <web.w.uvic. ca/masc/report.pdf>; the Canadian Institute Conference on B.C. Oil \& Gas Development held in Vancouver in December 2001; and Developing B.C. Offshore Oil and Gas, a conference sponsored by the Vancouver Island Branch of the Canadian Institute of Marine Engineering held in Victoria in June 2002. See also the Proceedings of the Canadian Petroleum Law Foundation's Inaugural East Coast Seminar in Oil and Gas published in (2001) 24 Dal. L.J. 1, for a discussion of regulatory issues arising recently on the east coast. 
We summarize the sources of law applicable to the west coast offshore area and provide a discussion of the preferred approaches to the development of an offshore regulatory regime in British Columbia, based in part on the experience over the last fifty years internationally and over the last thirty years ${ }^{2}$ with the regulatory regimes established on the east coast to regulate offshore oil and gas activities. ${ }^{3}$ This experience, together with the technological changes in offshore seismic and drilling industries since the early 1980s and changes in regulatory philosophies since that time, suggests that the regulatory regime currently existing on the east coast can be significantly improved upon in several important areas when developing a regulatory regime for west coast offshore oil and gas activity. ${ }^{4}$

\section{BRITISH COLUMBIA's OFFSHORE HYDROCARBON BASINS}

Three principal hydrocarbon basins have been identified offshore of British Columbia: the Winona \& Tofino Basin off the west coast of Vancouver Island; the Georgia Basin in the southern portion of the Georgia Strait between Vancouver Island and the British Columbia mainland; and the Queen Charlotte and Hecate Basins off the west coast of the British Columbia mainland and north of Vancouver Island. ${ }^{5}$

2 Since the early 1960s, more than 300 exploratory and development wells have been drilled in Atlantic Canada, cumulatively generating nearly $\$ 8$ billion in investment expenditures and creating over 100,000 jobs in the region: British Columbia Offshore HydroCarbon Developments: Report of the Scientific Review Panel (15 January 2002), online: Government of British Columbia <www. offshoreoiland gas.gov.bc.ca/reports/scientific-review-panel> [Report]. Oil production offshore Nova Scotia commenced in 1992 with the Cohasset/Panuke Project, and offshore Newfoundland in 1997 with the Hibernia Project, followed by the Terra Nova Project. The first offshore gas production commenced in December 1999 from the Sable Offshore Energy Project.

3 Shortly after the Supreme Court of Canada's decision in Reference Re the Seabed and Subsoil of the Continental Shelf Offshore Newfoundland, [1984] I S.C.R. 86 [Hibernia Reference], Canada and Newfoundland entered into the Newfoundland Accord, followed shortly thereafter by the Nova Scotia Accord. See Canada-Newfoundland Atlantic Accord Implementation Act, S.C. 1987, c. 3 [Newfoundland Act]; the Canada-Nova Scotia Offshore Petroleum Resources Accord Implementation Act, S.C. 1988, c. 28 [Nova Scotia Act]; and the provincial Canada-Newfoundland Atlantic Accord Implementation Act S.N. 1986, c. 37 [Newfoundland]; and the Canada-Nova Scotia Offshore Petroleum Resources Accord Implementation Act, S.N.S. 1987, c. 3 [Nova Scotia]. Section references in this article will be to the federal statutes, which will be referred to collectively as the Accord Acts. The respective Accord Acts and their regulations and guidelines can be found at the CanadaNewfoundland Offshore Petroleum Board (C-NOPB) and the Canada-Nova Scotia Offshore Petroleum, Board (C-NSOPB), online: <www.cnopb.nfnet.com > and <www.cnsopb.ns.ca>.

4 The nature of the offshore oil and gas industry has changed fundamentally since the 1970s, when the B.C. offshore moratorium was imposed, and the growth of knowledge and changes in technology available have been immense over the last fifteen years. Changes include the continued globalization of the industry, the introduction of new technologies (including 3D seismic, the development of directional drilling, automation, and the shift from fixed to floating production systems and subsea completions) and the changes in business practices (including greater outsourcing and contracting, the use of alliances and the pooling and sharing of assets among operators).

5 Drilling to date in the Queen Charlotte Basin, together with seismic studies and land-based geology, show abundant reservoir strata, presence of potential source rocks, numerous structural traps and frequent oil and gas shows. The latest Geological Survey of Canada in 1998 estimated that the Queen Charlotte Basin may contain up to ten billion barrels of oil and up to 40 trillion cubic feet of natural gas. If these estimates are confirmed by drilling, the Queen Charlotte Basin resource may be of a magnitude comparable to the Cook Inlet Basin of Southern Alaska, which has been in production for thirty years and is three times larger than the Hibernia field. However, given the complex geology and high degree of exploration risk associated with the area, years of seismic and drilling activity will be required to accurately establish the existence and magnitude, if any, of commercial reserves. The Geological Survey 
The main areas of current interest for offshore oil and gas exploration are the Queen Charlotte and Hecate Basins, extending roughly from the north end of Vancouver Island through Queen Charlotte Sound and the western portion of Hecate Strait including Dixon Entrance, and on the continental shelf west of the Queen Charlotte Islands out to the Queen Charlotte Fault. This area is estimated to contain 80 percent of British Columbia's offshore reserves and nine of its ten largest fields. ${ }^{6}$

The physical environment in the waters over the Queen Charlotte Basin are complex, but have similarities to producing offshore areas in the Cook Inlet of Alaska, the Grand Banks offshore Newfoundland, the Scotian Shelf offshore Nova Scotia, the Gulf of Mexico and California's offshore area. Although average drilling depths in the Queen Charlotte Basin are similar to those experienced on both the Scotian Shelf and the Grand Banks, wind conditions (particularly during the summer storm season) are more severe than on the east coast (though not as severe as in the Gulf of Mexico) and both local slope angles and spatial variability in bottom topography are much higher than those encountered on the eastern shelves. Climatic conditions are dominated by two atmospheric pressure systems: the North Pacific High, which dominates in the summer months, producing north-westerly winds; and the Aleutian low, which dominates in the winter months, producing winds from the south-east. Due to strong winds (up to $200 \mathrm{~km} / \mathrm{h}$ ), a complex bathymetry and large tidal exchanges, ocean currents and circulation patterns in the region are highly complex and highly variable. ${ }^{7}$ The area is prone to intense storms and is one of the most seismically active in the world, with the associated risks of earthquakes, slope failure and tsunami generation. ${ }^{8}$ Conversely, the risk posed by icebergs in the Grand Banks is non-existent on the west coast.

The Queen Charlotte Basin is geographically proximate to the Cook Inlet offshore the Coast of Alaska which has been in production since 1957, mostly using offshore platforms connected by pipeline to onshore terminals. Despite over forty years of production in Cook Inlet from six oil fields and three gas fields, there has been no documented evidence of any long-term degradation to the environment. ${ }^{9}$ The Cook Inlet has many direct geological and environmental similarities to the Queen Charlotte area, but more severe conditions, including ice, winter conditions and glacial out-wash, as well as some of the most extreme tides in the

of Canada estimates up to 6.5 TCF of natural gas in place in the Georgia Basin (two-thirds in Canada) with little potential for oil and 9.4 TCF of gas in place in the Winona \& Tofino Basins.

Queen Charlotte Sound extends from the northern tip of Vancouver Island, 500 kilometres north to Cape St. James at the southern tip of Moresby Island, at depths from 30 to 400 metres. Hecate Strait lies north of Queen Charlotte Sound, between the mainland and the Queen Charlotte Islands, extending roughly 55 kilometres from the mainland at its northern tip and approximately 120 kilometres at its northern tip, with depths from 40 to 300 metres. Dixon Entrance separates Graham Island from the islands of the southern Alaska panhandle at depths from 200 to 400 kilometres. West of the Queen Charlotte Islands the continental shelf is extremely narrow, extending out less than five kilometres in the south off Cape St. James, and 30 kilometres in the north, at depths to 200 metres. Beyond the shelf, water depths in the area of interest reach to 2100 metres. The areas thought most prospective for oil and gas development are southern Hecate Strait, Queen Charlotte Sound and eastern Graham Island and Dixon Entrance, in waters between 200 and $\mathbf{4 0 0}$ metres deep. These depths are common for offshore oil and gas activities. bottom and subsurface conditions and possible sea-flow hazards in the Queen Charlotte Basin. 
world. Similarly, the California offshore area, with 1412 offshore wells in 2000, has many geological similarities to the Queen Charlottes, including high levels of seismic activity. Weather and hydrographic conditions in the Queen Charlottes are also comparable to those in the North Sea.

The Queen Charlotte Basin is a diverse ecosystem. The region is home to six species of salmon, halibut, five stocks of herring and more than seventy species of groundfish, as well as invertebrates such as geoducks, intertidal clams, abalone, shrimp, crab and fifteen species of nesting seabirds. There are twenty species of marine mammals in the area, including whales, dolphins, porpoises, seals, sea lions, otter and mink. The Queen Charlottes are home to commercial fishing, aquaculture, sport fishing and the Alaskan tourist cruise industry. ${ }^{10}$

\section{THE History OF BRITISH COLUMbia OFFSHORE EXPLORATION AND THE MORATORIUMS}

The first offshore seismic activity in the Queen Charlotte basin took place between 1949 and 1958, followed by a provincially imposed moratorium from 1959 to 1966 on exploration drilling in the coastal water between Vancouver Island and Alaska.

Shell Canada Limited (Shell) acquired federal oil and gas exploratory permits in 1961 and, beginning in 1963, carried out seafloor geology mapping, aero-magnetic and seismic surveys in Hecate Strait and Queen Charlotte Sound. The provincial drilling moratorium was lifted briefly in 1966. Shell drilled fourteen exploratory wells in the offshore region between 1967 and 1969, from Barkley Sound north through Queen Charlotte Sound and Hecate Strait using a drilling rig built in Victoria, British Columbia. In 1970, Shell farmed out its offshore area permits to Chevron Canada Resources, who continued to carry out seismic surveys until 1972.

In 1970, British Columbia re-imposed its moratorium on oil and gas exploration in the Juan de Fuca and Georgia Straits, and in 1972 the federal government made a policy decision not to approve any new exploration permits or programs in the west coast offshore area and to suspend all work obligations under existing permits. The federal government also imposed a moratorium on crude tanker traffic from Valdez, Alaska through Dixon Entrance, Hecate Strait and Queen Charlotte Sound.

In 1981, as it had done previously in 1959 and 1966, British Columbia endeavoured to assert its jurisdiction by declaring the area landward of a line drawn off the west coast of the Queen Charlotte Islands south to the west coast of Vancouver Island as an Inland Marine Zone. Simultaneously, a moratorium was placed on offshore exploration in Johnstone Strait south of Telegraph Cove and in the Straits of Georgia and Juan de Fuca.

10 Ibid., has specifically recommended that action be taken to establish a comprehensive set of preperturbation baseline data on the biota, including life-cycle histories of different species and their habitats, and that an early assessment be made of sea-bottom and sub-surface conditions in the Queen Charlotte Basin and Hecate Strait areas. 
In 1982, Petro-Canada acquired three blocks of exploratory permits in Hecate Strait and Queen Charlotte Sound from the federal government in exchange for the relinquishment of certain northern blocks. Also in 1982, Chevron commenced efforts to lift the moratorium, submitting an initial environmental evaluation (IEE) to the federal Canada Oil and Gas Lands Administration. In 1983, Petro-Canada and the British Columbia provincial Ministry of Energy, Mines and Petroleum Reserves also submitted IEEs.

In September 1983, the federal Minister of Energy, Mines and Resources and the British Columbia Minister of Energy, Mines and Petroleum Resources signed an agreement to undergo a joint federal-provincial public review of the environmental and related socioeconomic effects of potential renewal of petroleum exploration on the west coast north of Vancouver Island. In 1984 and 1985, the West Coast Offshore Exploration Environmental Assessment Panel (Panel) conducted public hearings with First Nations and northern coastal communities to consider lifting the moratorium. A full research review of the IEEs was also conducted. The Panel delivered its report in April 1986, " concluding that exploration could proceed if specific requirements were met. Subsequently, the federal and British Columbia governments began to negotiate a Pacific Accord, detailing arrangements for revenue sharing and management of British Columbia's offshore petroleum resources.

In 1989, as a result of the Exxon Valdez crude oil tanker spill in Prince William Sound and the Nestucca Barge spill offshore Washington State, the federal and provincial governments imposed the current moratorium on offshore oil and gas activity for an initial five years and then extended it indefinitely with no mechanisms for review. The current provincial moratorium prohibits exploration and development in the Inland Marine Zone, as well as in the area between Vancouver Island and the British Columbia mainland, and the federal moratorium prohibits tanker traffic and exploratory drilling in Hecate Strait. In both cases the moratoriums are administratively imposed and could be lifted by policy announcements by the respective governments indicating a willingness to consider the recommencement of offshore activity. ${ }^{12}$

West Coast Offshore Exploration Environmental Assessment Panel, Offshore Hydrocarbon Exploration, a Report and Recommendation (1986).

12 Actually, it appears that no legislated moratorium is formally in place, either federally or provincially. In 1982, British Columbia declared the Queen Charlotte Basin to be an Inland Marine Zone and established regulations banning drilling (B.C. Reg. 10/82). Discussions commenced to lift the moratorium in 1982, but after the Exxon Valdez spill in 1989, the province announced that there would be no drilling for another five years and the federal government undertook not to proceed with authorization of further offshore activity in British Columbia until the province was prepared to do so. In 1994, a new provincial Order-in-Council (O.I.C. $248 \mathrm{~m}$, B.C. Gaz. 1994) and a new regulation (B.C. Reg. 55/94) revised Regulation 10/82, ending the formal prohibition on drilling. However, it remains the administrative policy of both levels of government that they will not entertain applications for new licences or for work under existing licences. Periodically the Frontier Lands management group of Resources Canada has issued letters notifying existing licence holders in the Queen Charlotte Basin that they have been relieved of work obligations and that their licences have been extended. Accordingly, "It appears that the current moratorium could be ended simply with a provincial decision to that effect, and a federal announcement agreeing that bids for licences or applications for permits to undertake exploratory work in specific parcels of offshore areas would be considered." (Report, supra note 2 at ii.) 


\section{Prior Technical, Environmental and Socio-Economic Studies}

There have been numerous studies commissioned and published over the years analyzing the technical, environmental and socio-economic aspects of west coast offshore oil and gas activity. In 1986, the West Coast Offshore Exploration Environmental Assessment Panel tabled its report on Offshore Hydrocarbon Exploration. ${ }^{13}$ The report recommended implementation of a regulatory regime designed specifically for west coast requirements, including joint government-industry contingency and spill-response plans. The report made ninety-two specific recommendations outlining the terms and conditions on which the panel believed that seismic activity and petroleum exploration could proceed in the west coast offshore area in a safe and environmentally responsible manner.

The report recommended that, prior to proceeding with seismic exploration, regional and Aboriginal participation and public information and education programs be established; that further studies be concluded on ocean currents and the native food industry; that meetings be held between seismic operators and the fishing industry; and that funding of community monitoring be arranged and a local supplier policy be developed. The report also recommended that, prior to commencement of drilling, further research on the local marine environment be undertaken, particularly on bird disturbance and fisheries impact, and that general sensitivity mapping, as well as specific mapping of food fishery and resource harvesting impacts, be completed.

In 1996, the COFRI Report ${ }^{14}$ reviewed the 1986 recommendations, and in 1998, the B.C. Premier's Advisory Council on Science and Technology tabled a further report prepared by AGRA Earth and Environmental Limited of St. John's, Newfoundland on the status of the west coast offshore and offshore development technologies, updating the 1986 Panel Report. ${ }^{15}$ In 1992 and 1993, the SPARK review for the Science Council of British Columbia outlined the potential for technological and economic opportunities in the British Columbia offshore area from ocean-related activities.

In 1999, the B.C. North Development Commissioner commissioned the B.C.-based Conflict Managers' Group to enquire into the willingness of stakeholders in northwest British Columbia to reconsider the moratoriums and to recommend a process for deciding the issue. ${ }^{16}$ The Conflict Managers' Group reported to the Northern Development Commissioner in February 1999 and August 2000. ${ }^{17}$

FEARO, Offshore Hydrocarbon Exploration: Report and Recommendations of the West Coast Offshore Environmental Panel (1986) at 123.

Report, supra note 2 at 1.

AGRA Earth and Environmental Limited of St. John's prepared its report on the status of the west coast offshore industry entitled Review of Offshore Development Technologies.

16. The North Development Commission was established pursuant to the Northern Development Act, S.B.C. 1998 , c. 17 , in July 1998 , to act as an advocate for northern development. It has undertaken a series of consultations with stakeholders on the prospects for oil and gas development.

17 For a summary of the Conflict Managers' Reports, see British Columbia Offshore Oil \& Gas Technology Update (19 October 2001), online: Government of British Columbia <www.em.gov.bc.ca/ oil \&gas/offshoreoil\&gastechupdate.htm> at 166 [Offshore Update]. In May 2002, the Offshore Oil And Gas Task Force, a six-member committee of Liberal caucus members of the provincial legislature, published a further report after holding a series of public hearings in northern coastal communities to 
In October 2001, the British Columbia Ministry of Energy and Mines released a further updated report entitled the British Columbia Offshore Oil and Gas Technology Update, prepared by Jacques Whitford Environment. The Whitford report summarized the latest offshore drilling and production technologies, their application to the safety of offshore oil and gas operations and the potential environmental effects of offshore oil and gas activities. The report concluded that there are no unique fatal-flaw issues that would rule out exploration and development activities:

In conclusion, the study has found that there are no specific design, geohazard or environmental issues that would preclude the development of the offshore oil and gas reservoirs of British Columbia. However, the economic viability of a specific reservoir may be adversely impacted by the costs associated with mitigating the geohazard and environmental risks. ${ }^{18}$

In January 2002, the government of British Columbia took delivery of the report of the Offshore Oil and Gas Scientific Panel established by the B.C. Ministry of Energy in October 2001. The Report of the Scientific Review Panel, released in April 2002, concluded as follows:

There is no inherent or fundamental inadequacy of science or technology, properly applied in an appropriate regulatory framework, to justify a blanket moratorium on such activities. With a firm commitment to comprehensive assessment of any proposals for specific offshore activities as provided in the existing legislative framework, and continuing commitment to ongoing principles of adaptive management and sustainable development, the existing policies maintaining an ongoing moratorium on hydrocarbon exploration and development offshore British Columbia can responsibly be ended. ${ }^{19}$

\section{Sources of LAW Applicable to the British Columbia OfFShORE ARea}

Currently, there is no regulatory regime in place specifically applicable to offshore oil and gas activity on the west coast. ${ }^{20}$

gain insight and input for developing British Columbia's offshore oil and gas resources. See the Task Force Report on Offshore Oil and Gas Development (30 April 2002), online: Government of British Columbia <www.em.gov.bc.ca/publicinfo/newsreleases/memnrs2002/memnrs002.htm>.

Ibid. at 172.

Report, supra note 2 at iii. In fact, the Report takes the position that the existing moratorium has been counterproductive and has "set back our understanding of the currents and oceans of British Columbia," and recommends that "it is time now to return marine scientific research to levels appropriate for a modern advanced society in general terms, and particularly as a basis for comprehensive, balanced and inclusive deliberations and assessment of specific proposals for BC offshore activity."

Onshore oil and gas resources are regulated by the B.C. Oil and Gas Commission, a provincial Crown corporation headquartered in Fort St. John, which regulates oil and gas activities and pipelines in the province pursuant to the Oil and Gas Commission Act, S.B.C. 1998, c. 39, the Petroleum and Natural Gas Act, R.S.B.C. 1996, c. 361, and the Pipeline Act, R.S.B.C. 1996, c. 364. The B.C. Ministry of Energy and Mines manages the province's petroleum resources to ensure environmental protection and worker safety and to collect revenues. The B.C. Ministry of Environment, Lands and Parks administers the Environment Management Act, R.S.B.C. 1996, c. 118, and regulates the management, protection and enhancement of the environment. The B.C. Environmental Assessment Office co-ordinates the impact assessment of major development proposals that are considered reviewable pursuant to the Reviewable Projects Regulation under the Environmental Assessment Act, R.S.B.C. 1996, c. 119 $[B C E A A]$, pursuant to a multi-staged project review and under the Canada-British Columbia Agreement for Environment Assessment Co-operation. The B.C. Land Use Co-ordination Office facilitates land 
As on the east coast, the underpinnings of any such regulatory regime would find its basis in customary international law and international treaties governing the territorial seas and the continental shelf. Additionally, maritime law, judicial decisions adjudicating Canadian and provincial jurisdiction over the west coast offshore areas, federal statutes such as the Oceans $A c t^{21}$ extending federal and provincial laws to the offshore, and federal acts pertaining to shipping and navigation, the marine environment and pipelines would apply. ${ }^{22}$

As in the eastern maritime provinces, it will be necessary to supplement this legal infrastructure with federal-provincial intergovernmental co-ordination and agreements and with legislation and regulations specifically governing offshore oil and gas activity in the west coast offshore area. ${ }^{23}$

\section{A. CUSTOMARY INTERNATIONAL LAW AND INTERNATIONAL TREATIES}

Canadian federal law is applicable to the west coast offshore areas not within provincial boundaries to the extent permitted by customary international law or treaty and as conferred by Parliament. ${ }^{24}$

Pursuant to the United Nations Conference on the Law of the Sea, ${ }^{25}$ a coastal state may extend its physical boundaries seaward for up to 12 nautical miles. Canada has done so pursuant to the Oceans $A c t .{ }^{26}$ Consequently, the Canadian federal government has absolute ownership of the sea and seabed and its content in the territorial sea (being the area extending 12 nautical miles offshore from a baseline drawn along the coastal low water mark and across inlets, but not departing appreciably from the direction of the coast) and exclusive jurisdiction to legislate over this area.

Pursuant to Article 77(1) of the LOS Convention and a similar provision in Article 2(1) of the 1958 Geneva Convention on the Continental Shelf, ${ }^{27}$ a coastal state has sovereign

use decisions.

$21 \quad$ S.C., 1996, c. 31.

22 Similar issues have arisen in the United States offshore area. In 1953, Congress enacted the Submerged Lands Act, 43 U.S.C. $\$ 1301$, which, generally speaking, granted the states interests in the resources of the seabed beneath the territorial sea, and the Outer Continental Shelf Lands Act, 43 U.S.C. $\$ 1332$, which applies federal domestic law on the continental shelf beyond the state's submerged lands and on offshore installations, while preserving the legal status of the surrounding waters as high seas and adopting the laws of adjacent states as part of the federal law to the extent that those state laws are not inconsistent with other federal laws. See L. Poe Leggette, "The Outer Continental Shelf Act Turns Fifty, Oil \& Gas Development on the Outer Continental Shelf" (Paper presented to the Rocky Mountain Mineral Foundation, April 2002).

2.3 The Accord Acts, supra note 3, incorporate by reference certain named provincial statutes dealing with social legislation, including workers' compensation, labour relations and occupational health and safety. The Franconia case (The Queen v. Keyn (1876), 2 Ex. D. 63) set out the basic requirements for domestic law to be applicable in the territorial sea; first, there must be a customary international law or treaty permitting the practise; and second, there must be an Act of Parliament which confers domestic jurisdiction. United Nations Conference on the Law of the Sea, UN Doc.A/CONF.62/122 (1982) not yet in force [LOS Convention].

27 Geneva Convention on the Continental Shelf, 29 April 1958, online: <www.oceanlaw.net/ texts/genevacs. htm>. 
control but not ownership over the living and non-living resources in its Exclusive Economic Zone (out to 200 miles) and a limited right of sovereignty over non-living resources only on the continental shelf beyond the 200 -mile limit. ${ }^{28}$

A coastal state has rights to the natural resources of the Continental Shelf and, specifically, exclusive sovereign rights for the purpose of exploring it and exploiting its natural resources, including mineral resources of the seabed and subsoil. States other than the coastal state are entitled to certain non-exclusive rights on the Continental Shelf, such as navigation, cablelaying and fishing rights.

\section{B. Federal and Provincial Legislation}

The Oceans $A c t^{29}$ confirms that the territorial sea (offshore from the low-water line to a distance of 12 nautical miles) forms part of Canada, and that the seabed and subsoil below it is vested in the federal Crown. In the contiguous zone, extending 24 miles from the territorial sea baselines, Canada can exercise jurisdiction for the prevention of infringement and enforcement of federal laws on customs, fiscal, immigration and sanitary matters. In Canada's Exclusive Economic Zone, extending for 200 nautical miles beyond its territorial seas, Canada has sovereign rights for the purpose of exploring, exploiting, conserving and managing natural resources.

Section 20(1) of the $O c e a n s ~ A c t^{30}$ provides that federal laws apply to marine installations and structures attached or anchored to the continental shelf in connection with the exploration for or exploitation of mineral resources, and within a regulatory prescribed safety zone surrounding such installations. Marine installations and structures include, but are not limited to, offshore drilling units, production platforms, sub-sea installations, pumping stations,

Although Canada has maximized its maritime zones using language in the Oceans Act which is almost verbatim from the text of the LOS Convention, it has not yet become a party to this treaty and has instead relied on customary international law. This approach gives rise to two uncertainties. First, on the east coast, Canada's continental shelf extends far beyond the Exclusive Economic Zone, but its outer boundaries have not been defined by the process established in the LOS Convention. However, Canada has granted several exploration licences and one significant discovery licence beyond the Exclusive Economic Zone. Canada's jurisdiction over these offshore areas is uncertain given its failure to ratify the treaty. Second, Article 82 of the LOS Convention imposes an incremental royalty payable to land-locked developing states on gross production starting at one percent in year six and escalating to seven percent by year twelve. Again, the applicability of this royalty is uncertain. See A. Chircop \& B.A. Marchand, "Oceans Act Uncharted Seas for Offshore Development in Atlantic Canada" Canadian Petroleum Law Foundation, Inaugural East Coast Seminar (September 2000), supra note 1.

The Oceans Act, supra note 21 , sets out a framework for the development of a national oceans management strategy designed to regulate marine ecosystems in accordance with principles of sustainable development and integrated management, and in accordance with the precautionary approach defined under the Rio Declaration on Environment and Development (14 June 1992, UN Doc. A/CONF.151/5/Rev. 1, 31 I.L.M. 874). The Canadian Association of Petroleum Producers (CAPP) has expressed concern over uncertainties as to the meaning of sustainable development in the context of non-renewable resource development and the implications of adopting a precautionary approach to resource development. See the internal discussion paper of CAPP's position on the Oceans Act (6 July 2000). 
living accommodations, storage structures and loading or landing platforms. ${ }^{31}$ Within these areas, federal laws are to be applied as if the marine installation and surrounding safety zone formed part of the territory of Canada, notwithstanding that, by their terms, the application of the particular law may be limited to Canada. Canadian laws are to be applied in a manner that is consistent with the rights and freedoms of other states in relation to navigation and overflight.

The Oceans $A c t^{32}$ also provides, in s. 9 and s. 21 respectively, for the application of provincial laws in the territorial seas and on marine installations and structures where such areas are prescribed by regulation..$^{33}$ To date, however, no such areas have been so prescribed, except in relation to the Confederation Bridge Area. ${ }^{34}$ The Accord Acts ${ }^{35}$ incorporated by reference certain named provincial statutes dealing with social legislation, workers' compensation, labour relations and occupational health and safety. In addition, the federal Hibernia Development Project $\mathrm{Act}^{36}$ makes applicable certain provincial legislation, primarily the Personal Property Security Act, ${ }^{37}$ in the Newfoundland offshore.

\section{Judicial Decisions Governing the British Columbia OfFShORE}

Two Supreme Court of Canada reference cases largely define the areas of the British Columbia offshore within federal and provincial jurisdictions respectively, but do not expressly adjudicate jurisdiction over the high prospect Queen Charlotte Basin.

The Canada Shipping Act, R.S.C. 1985, c. S-9, also applies to ships, broadly defined. The definition of ship is broad and may, for instance, include a self-propelled semi-submersible oil rig, a floating crane and possibly even jack-up drilling and production units. The Federal Court Act, R.S.C. 1985, c. F-7, adopts the definition of ship from s. 673 of the Canada Shipping Act. A line of cases have considered whether various types of objects used on the water constitute ships: floating cranes, barges built for use on water, rigs and submersibles. Significant factors in determining whether an object will be characterized as a ship include whether the object was built and designed to do something on water, whether it is capable of being moved from place to place and whether it is in fact moved from time to time.

Ibid.

Pursuant to s. 92 of the Constitution Act, 1867 (U.K.), 30 \& 31 Vict., c. 3, reprinted in R.S.C. 1985, App. II, No. 5 [Constitution Act, 1867], provincial laws are applicable only to lands "within a province." Clearly, however, pursuant to the principal of administrative inter-delegation, the federal government may also adopt as its own a provincial agency and delegate to it the power to regulate matters within exclusive federal jurisdiction. Similarly, pursuant to the principal of referential incorporation, one level of government can adopt the legislation or regulations of another level of government as its own.

Pursuant to The Confederation Bridge Area Provincial (PEI) Law Application Regulation, S.O.R./97375, the laws of Prince Edward Island, with the exception of the Highway Traffic Act, apply to the Confederation Bridge Area.

Supra note 3.

S.C. 1990 , c. 41.

S.N. 1999, c. P-7.1.

The authors gratefully acknowledge the assistance of Laura DeMunain of Davis \& Company in the preparation of this section. 


\section{THE BRITISH COLUMBIA OfFSHORE REFERENCE}

In Reference Re: Ownership of Offshore Mineral Rights (British Columbia), ${ }^{39}$ the Supreme Court of Canada held unanimously that the minerals of the seabed in the territorial sea and on the continental shelf offshore the west coast of Vancouver Island rest absolutely and exclusively with the federal government. The Supreme Court of Canada concluded that British Columbia had no historical, legal or constitutional basis upon which to claim that the territorial sea was part of British Columbia.

The Supreme Court of Canada considered the question of whether the territorial sea was part of British Columbia prior to and/or after Confederation, taking an extensive historical survey of pre-Confederation British Columbia, which focused largely on treaties. The analysis concluded that the territorial sea had not been within the boundaries of British Columbia prior to or at the time of its entry into Confederation. Similarly, the Supreme Court of Canada's analysis of post-Confederation British Columbia concluded that Canada has exclusive legislative jurisdiction with respect to the territorial sea based on s. 91(1)(a) of the Constitution Act, $1867^{40}$ and the residual power in s. 91 for "the peace, order and good government of Canada."

The Supreme Court of Canada looked to international law for guidance, and noted that rights in the territorial sea arise by international law and depend upon recognition by other sovereign states. Canada, as a sovereign state, is recognized by international law and is therefore able to enter into arrangements with other states respecting the territorial sea. British Columbia does not have the status of a sovereign state and cannot do so. Ultimately, it is Canada that will have to answer to the claims of other members of the international community for breach of the obligations and responsibilities with respect to the territorial sea.

The court concluded that British Columbia did not have any legislative jurisdiction over the territorial sea because it was outside its boundaries and, as such, the lands under the territorial sea did not fall within s. 92 of the Constitution Act, $1867^{41}$ since they were not within the province. Moreover, the mineral resources of these lands were of concern to Canada as a whole and went beyond local or provincial concern or interests.

\section{ThE GEORGIA StRAit REFERENCE}

Another Supreme Court of Canada reference case, Reference re: Ownership of the bed of the Strait of Georgia and related areas, ${ }^{42}$ dealt with the seabed and seabed resources under the waters between mainland British Columbia and Vancouver Island, namely the Strait of Juan de Fuca, the Strait of Georgia, the Johnstone Strait and the Queen Charlotte Strait (collectively, the "Georgia Strait Lands"). 
The important issue in this case was whether the Georgia Strait Lands were part of British Columbia prior to or after Confederation. After an extensive historical survey, the Supreme Court of Canada, in a four to one decision, concluded that the Georgia Strait Lands were within British Columbia when it entered Confederation and remained so afterwards. ${ }^{43}$

\section{An Act for the Union of the Colony of Vancouver Island with the Colony of British} Columbia ${ }^{44}$ set the westernmost boundary of British Columbia as the Pacific Ocean, giving the territory between the British Columbia mainland and Vancouver Island to the Colony of British Columbia. More specifically, the $1866 \mathrm{Act}$ defined the boundaries of the new and united colony of British Columbia as follows: "to the south by the territories of the United States ..., to the west by the Pacific Ocean ..., to the north by the sixtieth parallel ... and to the east ... by the Rocky Mountains." 45 The Court found that the words "territories of the United States" referred to the United States frontier defined by the Oregon Treaty of $1846,{ }^{46}$ namely the boundary line running through mid-channel of the straits separating Vancouver Island from mainland Washington State. In the Court's view, with that Treaty, Britain clearly asserted ownership over "all the territories" up to that mid-channel boundary. The Court noted that even if the word "territory" prima facie refers to dry land, history (that is, the Oregon Treaty), ${ }^{47}$ geography (Vancouver Island nestles into the mainland) and the express words of the $1866 \mathrm{Act}^{48}$ and its predecessors would displace this presumption.

In addition, the Court found that, on the true construction of this statute, the western boundary described as the "Pacific Ocean" can only refer to the open sea off the west coast of Vancouver Island, and not to the Georgia Strait Lands which have never been referred to as the Pacific Ocean. The boundaries established in 1866 did not change when British Columbia joined Confederation in $1871 .^{49}$

The Oregon Treaty, 1846 (Treaty with Great Britain, In Regards to Limits Westward of the Rocky Mountains, (United States and United Kingdom, 15 June 1846, 9 Stat. 869, T.I.A.S. 12:95)) set the boundaries between the United States and Britain, providing that the navigation of the whole of the channel and straits south of the 49th parallel would remain free and open to both parties. No other nation was given navigation rights south of the 49th parallel, nor was there any provision for free American navigation north of the 49th parallel, which included most of the Georgia Strait and all of Johnstone and Queen Charlotte Straits. The Court found that the demarcation of the 49th parallel and the mid-channel point in the straits as the international boundary constituted a recognition by each signatory of the claims of the other to proprietorship over all "the territories" up to that boundary. (U.K.), $29 \& 30$ Vict., c. 67 [1866 Act].

Supra note 42 at 389.

Supra note 43.

Ibid.

Supra note 44.

In contrast, in the Hibernia Reference, Newfoundland failed to establish that the continental shelf doctrine had become part of customary international law prior to it entering Confederation. The Court held that, while Newfoundland may once have been in a position to lay claim to its offshore areas, it surrendered this right when it joined Confederation. Newfoundland acceded its right to its offshore minerals when it joined Confederation in 1949 by not expressly maintaining jurisdiction over them. A prior Newfoundland Court of Appeal case, Reference Re: Newfoundland Offshore Rights (1983), 41 Nfld. \& P.E.I. R. 270, determined that the territory of Newfoundland includes a three marine-mile territorial sea, though it is not clear that this decision would be sustained if the case were reheard today. Nova Scotia's rights to its offshore have not been determined judicially, but given the reasoning of the Supreme Court of Canada in the B.C. Offshore Reference and the Hibernia Reference, and taking into account the territorial descriptions and circumstances of the pre-Confederation colony of Nova Scotia, it is virtually impossible to escape the conclusion that Canada, not Nova Scotia, holds the legislative 
When assessing the impact of the Georgia Strait Reference,${ }^{50}$ it is important to emphasize that there is an important distinction between the right of a government to exploit and utilize a resource, which is a proprietary right, and the right of a government to legislate in a given area. In the Georgia Strait Reference, ${ }^{51}$ the Supreme Court of Canada was careful to point out that the questions raised in that case were not concerned with legislative jurisdiction, nor with political or economic considerations. No questions were raised with respect to the power of the federal government in relation to matters within its exclusive legislative jurisdiction: the control of shipping, navigation, trade and commerce, customs, fisheries and defence. The sole question was the issue of the proprietorship of the lands. Even though lands may be within a province, the federal government retains a significant right to legislate pursuant to the federal constitutional heads of power. For example, even in offshore areas under provincial jurisdiction, the federal government has the right to regulate matters, such as shipping and navigation, the marine environment and pipelines that cross provincial or international boundaries. ${ }^{52}$ Similarly, where an area is under federal jurisdiction, laws regulating matters under provincial jurisdiction, such as those governing property and civil rights and the regulation of security interests and workers' compensation, will apply where made specifically applicable.

\section{A HECATE STRAIT REFERENCE?}

These two decisions of the Supreme Court of Canada have judicially resolved federal-provincial jurisdictional issues as they pertain to British Columbia's offshore west of Vancouver Island (location of the Winona/Tofino Basin), which is clearly under federal jurisdiction, except for the southern tip extending into the Strait of Juan de Fuca and the Georgia Strait (location of the Georgia Basin), which are clearly lands within the province, except for the portion extending down into offshore Washington State.

Ownership of the high prospect areas in the Queen Charlotte and Hecate Strait has not yet been litigated, and as such it is unclear whether this area is part of the territorial sea and the Exclusive Economic Zone, or whether it is within the boundaries of British Columbia on the same basis as Georgia Strait. Existing exploratory licences in the area have been issued by federal authorities. At the same time, however, early historical references include Graham Island in the Colony of Vancouver Island, and the province has continued to assert jurisdiction over the Queen Charlotte Basin by issuing three separate Orders-in-Council declaring the area an Inland Marine Zone and reserving the seaboard floor off the Queen Charlotte Islands and Vancouver Island to the provincial Crown. ${ }^{53}$

powers in the territorial sea and Continental Shelf off Nova Scotia. See V. Penick, "Legal Framework in the Canadian Offshore" (2001) 24 Dal. L. Rev. 1.

Supra note 42.

Ibid.

The jurisdiction of the National Energy Board arises out of its regulatory authority over the construction and operation of pipelines which form part of an interprovincial work or undertaking, and if a direction is made pursuant to s. 124, in relation to movement of designated oil and gas out of the offshore area. Nova Scotia has similarly endeavoured to assert jurisdiction over security interests in real and personal property in its offshore area by way of its Petroleum Resources Removal Permit Act, S.N.S. 1999, c. 7. 
This jurisdictional impasse must be resolved by federal-provincial agreement or by a Hecate Strait Reference prior to the commencement of substantial offshore oil and gas activity in the area. Litigation would be acrimonious and time-consuming. We recommend a federal-provincial agreement or Pacific Accord, along the lines of the Atlantic and Northern Accords, as the practical solution.

\section{The Aboriginal Consultative Process}

The asserted traditional territories of a number of First Nations are situated in the regions of the British Columbia offshore prospective for oil and gas exploration. ${ }^{54}$ These include the Haida and the Council of Haida Nations on the Queen Charlotte Islands (Haida Gwaii); the Nisga'a (Nisga'a Lisims Government) at the mouth of the Nass River and in the Nass River; the Tsimshian First Nations (Tsimishian Tribal Council), Haisla Nation and Heiltsuk First Nation on the north and central coast; and the Winalagalis Treaty Group and Kwaguilth First Nations on northern Vancouver Island. Canadian governments have never acknowledged Aboriginal rights to seabed resources.

The process of developing management, revenue-sharing and local benefits regimes applicable to the west coast offshore oil and gas resources must, from the outset, involve consultation with Aboriginal groups and accommodation of their interests. Without such accommodation, it will not be possible to achieve an acceptable level of business certainty to enable industry participants to commit the capital and other resources necessary for exploration and development.

Unfortunately, there exists in British Columbia a degree of cynicism as to whether an Aboriginal consultative regime can be put in place with respect to the offshore that will achieve a sufficient degree of clarity and stability of outcome for Aboriginal people, governments and industry within an acceptable period of time.

Due to the critical importance of the offshore to British Columbia's economic future, Aboriginal concerns must be taken seriously and every effort made to devote the resources necessary to achieve a result that fairly and genuinely balances Aboriginal interests and resource development, and that will withstand judicial scrutiny. Such a result is likely to include meaningful Aboriginal participation on any eventual Pacific Offshore Resources Board, early Aboriginal employment and business opportunities, benefit and revenue sharing with Aboriginal communities, and the implementation of stringent measures to mitigate the potential environmental and social impacts of resource development.

Section 35 of the Constitution Act, $1982^{55}$ recognizes and affirms the Aboriginal and treaty rights of Aboriginal peoples in Canada. Much has been learned from the ongoing litigation in the twelve years since the decision of the Supreme Court of Canada in $R$. v. Sparrow ${ }^{56}$ about how to conduct an appropriate consultative process that fairly accommodates 
Aboriginal interests. ${ }^{57}$ This learning must now be applied fully in developing an Aboriginal consultative process for the offshore that fully and fairly balances Aboriginal interests and resource development. ${ }^{58}$

Pursuant to the B.C. Treaty Commission Agreement signed on 21 September 1992, tripartite negotiations are underway with most of the Coastal First Nations through the sixstage B.C. treaty negotiation process, with only the Nisga'a having completed the process. ${ }^{59}$ Resolution of west coast offshore issues cannot wait for the results of this treaty negotiation process. Rather, a separate and specific process must be put in place to reach accommodation with Aboriginal groups having a stake in the Queen Charlotte Basin.

A number of First Nations have issued statements supporting continuation of the offshore moratorium. In May 2001, the Tsimshian and Haida Nations issued a statement supporting the moratorium on the basis that the petroleum interests are within their territorial seas and because "the risk of harm from an accidental oil spill or allowable discharge is not acceptable." In October 2001, the Chief of the Lax Kw'alaams Band expressed concerns about possible negative environmental impacts, risks to marine resources and the potential negative social risk to their culture.$^{60}$ In February 2002, the Haida Nation filed a lawsuit claiming Aboriginal title to the whole of the Queen Charlotte Islands, as well as asserting that no oil and gas development could take place off the coast of British Columbia without their permission, as they also claim title to the seabed surrounding the Queen Charlotte Islands.

In Delgamuukw v. British Columbia, [1997] 3 S.C.R. 1010 [Delgamuukw], the Supreme Court of Canada reaffirmed that Aboriginal title does exist in Canada, and that, where justified, it may be infringed upon for valid public purposes after an appropriate consultative purpose.

See T. Isaac \& A. Knox, "The Crown's Duty to Consult Aboriginal People" in this issue at 49, who submit that the case law on the Crown's duty to consult Aboriginal people, coupled with basic principles of procedural fairness, provide sufficient guidance to government as to how to conduct an Aboriginal consultative process that will sustain legal challenge and provide sufficient certainty to the business community to permit resource development. All that remains is for governments to embrace the lessons of the case law, rather than adopting a piecemeal and minimalist approach to reforming their consultative processes

The Nisga'a Treaty has been ratified by the Nisga'a Nation. Legislation granting approval by the governments of Canada and British Columbia, and bringing the treaty into effect, was passed in early 2000. The Nisga'a Treaty provides for the grant of fee simple title to a portion of the land within the traditional territory claimed by the Aboriginal group and the payment of compensation. It also provides for the Nisga'a government to have defined law-making powers over its lands and its members. The Nisga'a Treaty contemplates that future rights and interests within the treaty title lands will be subject to negotiation with the Nisga' a government and to potential payment of fees, royalties and other charges to the Nisga'a government. Two provincial protocol agreements will also shape the nature and degree of native involvement in offshore oil and gas issues. The protocol agreements between the provincial government and various First Nations recognize a greater involvement of First Nations in the management of natural resources within their claimed territories, and include mechanisms for addressing ecological and environmental issues in developing a strategic land-use plan within the province. With respect to conventional oil and gas operations in northeastern British Columbia, the provincial Oil and Gas Commission has conducted a consultative process and has entered into memoranda of understanding with various First Nations. These memoranda define a framework for consultation about the impacts of oil and gas activity designed to increase predictability, and provide timelines and operational guidelines for inclusion. See online: Government of British Columbia $<w w w . o g c . g o v . b c . c a / f i r s t n a t i o n s$. asp $>$. 
Prior cases from the Supreme Court of Canada, including $R$. v. Guerin, $R$. v. Sparrow and Delgamuukw, ${ }^{61}$ established that governments have a duty to consult with an Aboriginal group as a precondition to infringement of Aboriginal rights or title. It has previously been understood that the Crown's obligation to consult does not arise until the right or title has been proved in court or accepted in a treaty. However, two recent decisions of the British Columbia Court of Appeal have reversed prior case law and have held that the government's obligation to consult arises simply on the assertion of a right, or even as a result of government's knowledge of the potential existence of a right. Moreover, one of the cases suggests that private industry, as well as the Crown, has a positive duty to consult with Aboriginal interests.

In each of these two decisions, Taku River Tlingit First Nation v. Tulsequah Chief Mine Project ${ }^{62}$ and Haida Nation v. British Columbia (Minister of Forests), ${ }^{63}$ an Aboriginal group asserted (but had not yet proven) the existence of constitutionally-protected Aboriginal rights to the land that was the subject of development. In each case, the issue arose as to whether the Crown had a positive legal obligation to consult with them before allowing development to proceed. In Taku River, ${ }^{64}$ the Court of Appeal held that the Crown has a constitutional or fiduciary duty to consult with a First Nation who asserts rights or title to lands subject to development, even before those rights are proven to exist.

The Haida Nation ${ }^{65}$ case concerned a legal challenge to Weyerhaeuser's tree-farm licence for logging operations on the Queen Charlotte Islands. The Court of Appeal confirmed that the Crown has a legally enforceable duty to consult with a First Nation that has a reasonably founded assertion of Aboriginal rights or title to affected lands (even before those rights or title have been proven to exist), but also extended this duty to consult to a proponent of development who seeks governmental approval for its operations.

The Court of Appeal added that the degree to which an Aboriginal group must be consulted depends on the apparent strength of its case for Aboriginal title: "the scope of the consultation and the strength of the obligation to seek an accommodation will be proportional to the potential soundness of the claim for Aboriginal title and Aboriginal rights." ${ }^{66}$ The Court further ruled that both the Crown and industry have a positive obligation, where an Aboriginal group asserts a claim to land, to make inquiries as to whether those claims are in fact reasonably founded.

\section{CO-ORdiNATED FEDERAL-PROVINCIAL ENVIRONMENT REVIEW AND ASSESSMENT}

Over the last twenty-five years, a series of technical, scientific and environmental reports (in 1986, 1996, 2001 and 2002) have studied the desirability of lifting the west coast offshore

Guerin v. The Queen, [1984] 2 S.C.R. 33; Sparrow, supra note 56; Delgamuukw, supra note 57. 2002 BCCA 59 [Taku River].

2002 BCCA 147 [Haida Nation]. The issue of whether Weyerhaeuser owed the Haida a duty of consultation was argued before the British Columbia Court of Appeal in early June 2002.

Supra note 62.

Supra note 63.

Ibid. at para. 51 
moratorium. Each of these general studies has concluded that both the state of our knowledge of environmental impacts and the technology available to mitigate these impacts have progressed to the point where the moratorium can be prudently lifted. We believe that, given the volume and quality of this prior work, more general studies are no longer required.

Obviously, however, environmental assessment of specific project proposals is necessary. However, industry must be provided with certainty that the necessary federal and provincial environmental assessments will proceed in a highly co-operative and co-ordinated fashion.

Both the Canadian Environmental Assessment $A c t^{67}$ and the British Columbia Environmental Assessment $A c t,{ }^{68}$ as well as any implementation act resulting from a Pacific Accord, would apply to any offshore project either pursuant to the $C E A A^{69}$ law list requirements under the federal Fisheries $A c t^{70}$ or the provincial Reviewable Projects Regulation, ${ }^{71}$ or pursuant to a discretionary designation by the respective ministers. ${ }^{72}$

Fortunately, pursuant to a bilateral agreement negotiated under the Canada-Wide Accord on Environmental Harmonization, ${ }^{73}$ Canada and British Columbia have agreed to co-operate in environmental assessments. Technically, this agreement expired in April 2002, but it has been extended on an interim basis pending completion of significant revisions to both the federal and provincial environmental assessment legislation. ${ }^{74}$

To date, there have been thirteen environmental assessments completed or underway under the Canada-B.C. agreement and nation-wide. There have been at least three co-operative federal-provincial assessments of oil and gas mega-projects: the Sable Island offshore drilling, submarine pipeline and onshore processing project; the Terra Nova offshore oil project on the Grand Banks; and the proposed Georgia Strait Crossing Project to build a gas pipeline from Washington State to Vancouver Island.$^{75}$ These co-ordinated federal-provincial

S.C. 1992 , c. $37[C E A A]$.

Supra note 20.

Supra note 67.

R.S.C. 1985 , c. F-14.

B.C. Reg. 276/95.

For a recent description of the east coast offshore environmental assessment regime, see G. van Driel \& A. MacDonald, "Environmental Regime for Development of an Oil and Gas Project in the Newfoundland Offshore" (2002) 40 Alta. L. Rev. 131.

Canadian Council of Ministers of the Environment, A Canada-Wide Accord on Environmental Harmonization (Ottawa: CCME, 1998).

Currently Bill C-19, amending the $C E A A$, is going through cabinet revision and is expected to receive Royal assent in the Fall. The provincial bill, which will effect a dramatic revamp of the $B C E E A$, is scheduled to be proclaimed in six months.

Assessments of the likely cumulative impacts of ongoing offshore production activities have been completed as part of the environmental assessment of each of the recent east coast offshore projects. In 1997, the Sable Gas Projects Panel concluded that the project is not likely to result in significant adverse cumulative environment effects. The Environmental Impact Statement (EIS) for the Terra Nova Development Project concluded that offshore activities would result in minor (not significant) effects to water quality and benthos, minor (not significant) local effects to marine mammals, negligible effects to populations due to noise and negligible effects due to oily water discharges. Similarly, the EIS for the White Rose Project assessed that the cumulative impact of the project, together with commercial fishing, hunting and vessel traffic would be a non-significant impact on marine mammals and seabirds. 
reviews provide a template which should be adopted and followed in the eventual environmental assessment of any eventual west coast offshore oil and gas project.

\section{A. ENVIRONMENT IMPACTS OF OFFSHORE OIL AND GAS ACTIVITIES}

Each phase of offshore oil and gas activity has environmental impacts. In addition, environmental damage can result from spills and blowouts. ${ }^{76}$ Technological changes and industry experience have dramatically reduced environmental impacts over the last sixty years, in which the oil and gas industry has seen "new knowledge, new designs, sophisticated regulation and greater public awareness and concern have continued to result in dramatic advances and improvements in offshore exploration and production, particularly over the last decade." "77 Nevertheless, the recent Report of the Scientific Review Panel recommends that, before offshore activity is commenced in the Queen Charlotte Basin, "it is critical to establish a complete set of pre-perturbation baseline data on the biota, including life-cycle history, and their habitats, so that we can understand and assess which aspects of the marine ecosystem are at risk from the proposed development and evaluate the population and community-level consequences that may result following development."78

Seismic activity involves the creation of loud blasts. The use of airguns has replaced the use of environmentally unfriendly chemical explosives. Furthermore, recent advances have dramatically improved the acquisition, processing and interpretation of airborne gravity and magnetic surveys. Since the mid 1970s, 3D seismic exploration, involving the simultaneous recording of multiple reflected acoustic waves by a set of parallel arrays of hydrophones, coupled with improved computer processing capabilities, has generated significantly greater information and has consequently improved drilling results.

Seismic shooting has been shown to affect fish distribution within an 18 to 20 nautical mile radius, and can cause mortality to fish, eggs and larvae in the immediate vicinity. The low- frequency sound waves can also disorient mammals depending on them for communication. The Report has recommended that British Columbia impose guidelines under licensing conditions similar to those recently established by the Joint Nature Conservation Committee in the United Kingdom for reducing the impact of seismic exploration on marine animals. ${ }^{79}$

The principal environmental impact of exploratory drilling, which with modern technology would not likely be carried out by a semi-submersible or drilling ship, is the deposition of drilling muds used as lubricants to cool drilling bits and flush cuttings on the ocean floor (typically within 50 to 100 metres of the bore hole). Water-based muds are used for shallow exploration, and oil or less toxic synthetic-based muds are used for deeper drilling.

The Report, supra note 2 at 38, concludes as follows: "Offshore hydrocarbon exploration and development cannot be undertaken without impacts on the environment. The subject area is a sensitive one and care is needed in any development. The objective should be to maintain risks at an acceptable level and to mitigate them."

Ibid. at 3.

Ibid. at 31 .

Ibid. at 33 . 
Technological advances such as horizontal multilateral drilling, dynamic positioning systems, and improvements in blow-out preventer (BOP) design have reduced the environmental impact of exploration drilling. Canada's existing offshore regulations require the use of less toxic synthetic drilling muds and, subject to a risk/reward assessment, it is technologically possible to require the re-injection of drill cuttings and produced water.

Although mammals, fish and squid appear attracted by the operating lights associated with drilling operations, the effects on their populations appear to be negligible. Birds can become disoriented by lights and flares, particularly in overcast or foggy weather, but again, the instances of disorientation appear to be few. ${ }^{80}$

Under current technology, production in the Queen Charlotte Basin is most likely to take place using a tension leg platform. Production results in saline water and atmospheric impacts from flaring, venting and purging gases. Worldwide, offshore oil production (including spills and blowouts) contributes only about two percent of ocean-based pollution; industrial and municipal discharge contributes 37 percent, vessel operations 33 percent, tanker accidents 12 percent, and natural seeps seven percent. ${ }^{81}$ The Scientific Review Panel has recommended that export lines from production platforms in the Queen Charlotte Basin be tied into pipelines as opposed to offloading the oil into shuttle tankers by way of buoys. ${ }^{82}$ They go on to recommend that pipeline monitoring and shutdown systems should be employed to maintain maximum pipeline integrity and the least possible environmental risk. Suitable surveying would be required to establish the most secure pipeline route. The Canadian Standards Association (CSA) Code for Offshore Structures ${ }^{83}$ has established engineering design requirements for offshore structures in the Canadian environment.

\section{B. Combined Federal-ProvinCial OfFShORE EnVIronmental REVIEW AND ASSESSMENT}

Both the $C E A A^{84}$ and the $B C E A A^{85}$ would apply to exploratory drilling in the west coast offshore area, the former by virtue of the $C E A A$ law list requirements under the federal Fisheries $A c t^{86}$ and the Navigable Waters Protection Act, ${ }^{87}$ and the latter through s. 31 of the $B C E A A$ Reviewable Project Regulation. ${ }^{88}$ In addition, both the $C E A A^{89}$ and the $B C E A A^{90}$ contain clauses permitting the respective responsible ministers to designate a project, such as a seismic program, for review at their discretion.

See the Appendix to Report, ibid. Only one blow-out has occurred in eastern Canada, involving loss of only about 1500 barrels of condensate.

Ibid. at 3.

Ibid. at 34

See Appendix 18 to Report, ibid.

Supra note 67.

Supra note 20.

Supra note 70.

R.S.C., c. N-19, s. 1.

B.C. Reg. 276/95.

Supra note 67.

Supra note 20. 
Section 40 of the $C E A A$ provides for joint environmental assessment review panels on a case-by-case basis, and s. 58(1)(c) permits the federal Minister of the Environment to enter into federal-provincial agreements or arrangements for assessment processes. ${ }^{91}$ Section 42 further states that, "Where the Minister establishes a review panel jointly with a jurisdiction referred to in subsection 40(1), the assessment conducted by the panel shall be deemed to satisfy any requirements of this Act and the regulations respecting assessments by a review panel." Section 59(i)(v) establishes the power to make regulations to adapt the $C E A A^{92}$ assessment processes for the Offshore Boards. Similarly, the Accord Acts ${ }^{93}$ allow cooperative environmental assessment processes and require the Offshore Boards to avoid duplication of work and activities by consulting with appropriate departments and agencies of the federal and provincial governments to develop memoranda of understanding in relation to environmental regulation.

In January 1998, the Canadian Council of Ministers of the Environment approved the Canada-Wide Accord on Environmental Harmonization, ${ }^{94}$ including a sub-agreement on environmental assessment aimed at realizing "better environmental protection by promoting co-operation, achieving efficiency and greater certainty in environmental assessment processes and establishing accountability in environmental assessments involving more than one jurisdiction." The sub-agreement applies where two or more governments are required by law to assess the same proposed project and provides for a common framework under which bilateral agreements can be developed between the federal government and individual provinces. The Canada-British Columbia Agreement for Environmental Assessment Cooperation, ${ }^{95}$ agreed to in 1967 , provides for notification and co-operation between the federal and British Columbia departments and agencies when undertaking assessments. Thirteen co-operative environmental assessment have been completed or are underway. ${ }^{96}$

Canada-wide, there have been three formal co-operative federal-provincial environmental assessments conducted under the $C E A A$ for oil and gas projects: the Sable Offshore Energy Project involving the construction of offshore drilling and production facilities, a submarine pipeline and an onshore natural gas processing plant in Nova Scotia; the Terra Nova Development proposal to develop the petroleum resources of the Terra Nova oil field on the northeast Grand Banks of Newfoundland; and the proposal by Georgia Strait Crossing Pipeline Limited to construct a gas pipeline from Washington across the Strait of Georgia and onto Vancouver Island.

The experience to date with the co-operative environmental assessment process is that a lengthy lead time is required to both establish the processes to be used in the co-operative environmental assessment and to formalize them in a memorandum of understanding. It

\footnotetext{
Supra note 67.

Ibid.

Supra note 3.

Supra note 73.

Government of Canada, online: <www.ceaa-acee.gc.ca/0009/0001/0003/0001/0002/canada-bcagr_e.htm>.

* A mandated five-year review of the $C E A A$ led to the revisions proposed in Bill C-19, tabled in March 2001. Similarly, the $B C E A A$ is currently subject to reassessment under the B.C. government's core services review program. The present sub-agreement with British Columbia under the Canada-Wide Accord on Environmental Harmonization expired in April 2002 and is in the process of being renewed.
} 
simply takes time to meld the different assessment and regulatory processes established by different tribunals which often also have different hearing procedures and natural justice requirements. ${ }^{97}$

The co-ordinated environmental review and assessment of major energy projects, including offshore projects, has worked well. The existing arrangements under the CanadaWide Accord on Environmental Harmonization ${ }^{98}$ and the Canada-British Columbia Agreement for Environmental Assessment Cooperation ${ }^{99}$ should be renewed with such improvements as may be warranted by experience over the last five years.

\section{A PACIFIC ACCORD - AdAPTING THE EAST COAST EXPERIENCES}

On the east coast, conflicting jurisdictional claims to the offshore resources were resolved through political accommodation. Uncertainty over jurisdiction resulted in the development of a co-operative regime operating pursuant to the principles of administrative interdelegation and referential incorporation to manage and administer the offshore. ${ }^{100}$

The Government of Canada delegated to the province, and to the federal-provincial bodies created under the legislation, the administration of the offshore oil and gas regime and adopted by referential incorporation various provincial statutes governing offshore oil and gas exploration and exploitation. ${ }^{101}$

In the case of the Sable Gas Project, for example, co-ordination was required between the Ministers of the Environment for Canada and Nova Scotia, the Ministers of Natural Resources for Canada and Nova Scotia, the National Energy Board and the C-NSOPB for the establishment of a review process that would meet the requirement of the CEAA, the Nova Scotia Environment Act and the National Energy Board Act, as well as the Nova Scotia Accord Implementation Acts. A joint review panel was constituted consisting of two full-time National Energy Board (NEB) members, a third member who sat as a temporary member of the NEB, a Commissioner under the Accord Acts who sat as a member of the federal-provincial joint panel, and one member who sat solely on the joint review panel. A single public review process allowed for the collection and examination of evidence and the hearing of arguments on environmental effects for use in the subsequent deliberations and decision-making by each of the participating regulatory authorities. The terms of reference for the joint panel stipulated that the panel's review processes would include the NEB Rules of Practice and Procedure, which provide for sworn testimony, cross-examination and argument.

In the case of the Terra Nova Project, a memorandum of understanding establishing a joint panel and a single process for assessing the project was implemented under the $C E A A$ and the Newfoundland Act. Similarly, in the case of the Georgia Strait Pipeline Crossing Project, a Memorandum of Understanding between the province of British Columbia, the NEB and the federal Department of Fisheries and Oceans co-ordinated the preparation of a comprehensive study report.

Supra note 73. Supra note 95.

(10) In the Yukon, the governments of Canada and the Yukon signed a Yukon Oil and Gas Accord, infra note 135. The Yukon subsequently enacted the Yukon Oil and Gas Act, S.Y. 1997, c. 16, to regulate in areas of devolved responsibilities. In the Northwest Territories, the federal and NWT governments entered into an Agreement in Principle regarding a Northern Accord in 1988. No Accord has subsequently been entered into. See R.E. Quesnel, "A Review of the Canada Petroleum Resources Act and the Canada Oil and Gas Operations Act as the Legal Framework for Future Development in the Northwest Territories" (2002) 40 Alta. L. Rev. 83.

101 For example, both of the current Accord Act regimes apply provincial social legislation, including workers compensation, labour standards and occupational health and safety legislation to offshore marine structures and installations. Clearly, it is within federal competence to adopt a provincial agency and to delegate to that provincial agency the power to regulate matters normally within exclusive federal 
First Newfoundland and then Nova Scotia entered into accord agreements in which they put aside their jurisdictional claims and established a stable joint regulatory framework administered by quasi-independent boards by way of intergovernmental agreement and mirror federal and provincial legislation. The Accord $A c t^{102}$ regimes have proven to be an enduring long-term solution to intergovernmental regulation, resource management and revenues/benefit sharing concerns on the east coast. In working out the ideal British Columbia-Canada arrangement, the Newfoundland and Nova Scotia offshore oil and gas legal regimes are an obvious point of reference.

Various commentators have assumed that, if offshore oil and gas exploration and development were to proceed on the west coast, a Pacific Accord would be put in place basically mimicking the regulatory regime already in place in the Atlantic provinces. ${ }^{103}$ Certainly, one might expect that this would be the preference of the federal government (assuming equal willingness to cede operational control and royalty revenue base to British Columbia as shown with respect to Newfoundland and Nova Scotia), as it would result in administrative convenience and consistency between oil and gas regulatory regimes in the east and west coast offshore areas and in the northern territories. ${ }^{104}$ Also, by using the east coast regulatory regime as a template, a pretested and familiar regulatory regime could be implemented relatively quickly on the west coast.

At the same time, however, the emergence of offshore oil and gas activity on the west coast provides an opportunity to design a more responsive regulatory regime, including "white sheet" solutions, building upon the history of regulatory experience on the east coast under the Accord Act regimes and recognizing the dramatic technological changes that have occurred in the offshore industry, as well as the shift from prescriptive to result-oriented regulatory philosophies that have occurred during that time period. ${ }^{105}$ Worldwide, there is now a half-century of offshore experience, and in Canada, three decades of experience with offshore oil and gas operations off the coasts of eastern Canada. Technology is superior to that of just a decade ago. The recently released Report has, for example, observed that "new knowledge, new designs, sophisticated regulation and greater public awareness and concern

jurisdiction. One level of government can also incorporate the legislation of the other by reference into its own. However, legislative inter-delegation is not constitutional. One legislative body cannot enlarge the powers of the other by authorizing the latter to enact laws which are ultra vires the power of that legislative body. For a detailed description and analysis, including a discussion of the applicable case law, see A.T. Pettie, "Are Royalty Agreements Required for Canada East Coast Offshore Oil and Gas?" (2001) 24 Dal. L.J. 151. Supra note 3.

103 See e.g. the British Columbia Offshore Oil and Gas Technology Update (19 October 2001), supra note 17 , which states, without detailed consideration, that "[i]n a broader context, it can be assumed that any initiative to lift the moratorium and resume exploration activity will be followed by the implementation of some form of federal-provincial regulatory mechanism based on legislation similar to the Atlantic Accord and the Accord Act." Report, supra note 2 at 4, comments that "[w]hile there are differences in geological and other environmental aspects of the Atlantic offshore, it is of critical importance in providing a well-established regulatory framework on which to build for any B.C. offshore oil and gas exploration and development." Supra note 3.

105 For example, as a dramatically different alternative to the Accord Act regimes, licensing, benefits and royalties could be assigned to the province, and operational, safely and environmental issues left to the NEB. 
have continued to result in dramatic advances and improvements in offshore exploration and production, particularly over the last decade, ${ }^{106}$ and that any newly designed regulatory regime should sensibly be responsive to such developments.

Any eventual Pacific Accord should sensibly incorporate improvements and modifications based upon the learning derived from the Atlantic experience over the last twenty-five years and should be responsive to ongoing technological advances. This portion of our article examines the Atlantic experience in each of the principal areas of regulation prescribed by the regulatory regimes applicable in the Atlantic provinces, and tables for consideration alternative approaches derived from that experience.

\section{A. BACKGROUND ON THE EAST COAST REgULATORY REgIMES}

The east coast regimes were initiated by the Mulroney government in the 1980 s as a direct response to the intrusive National Energy Program of Pierre Elliott Trudeau and its centrepiece for the offshore, the Canada Oil and Gas Act. ${ }^{107}$ Under that Act, the federal Minister of Energy Mines and Resources had enormous discretion - many would have said an overbearing discretion. Progressive incremental royalties were extremely high, and the federal Crown had a back-in right into offshore production, which it could exercise in favour of then-publicly owned Petro-Canada. The legislation imposed Canadian ownership restrictions on oil companies and, through the companion Petroleum Incentives Program $A c t,{ }^{108}$ induced Canadian companies with enormous grant incentives to explore for hydrocarbons on Canada's continental shelf. Provincial involvement was nil - that was the whole point of the National Energy Program. The offshore was managed by the Canada Oil and Gas Lands Administration and royalties went to Ottawa.

The current legislation was brought into force in 1987 in Newfoundland and in 1988 in Nova Scotia, and is essentially similar in the two provinces. The Accord Acts ${ }^{109}$ and accompanying regulations and offshore board guidelines and policies make up the regulatory framework which governs oil and gas operations on the east coast. ${ }^{110}$ These statutes establish

Canada first asserted regulatory authority over offshore oil and gas resources and operations in the Canada Oil and Gas Lands Regulations promulgated in the early 1960s under the Public Lands Grant Act, R.S.C. 1985 , c. P-30, repealed by S.C. 1991 , c. 50 , s. 50 , which were in turn replaced with the Canada Oil and Gas Act and the federal Oil and Gas Production and Conservation Act, which were eventually superseded by the current federal statutes, namely the Canada Petroleum Resources Act, R.S.C., 1985, c. 36 (2d Supp.), and the Oil and Gas Operations Act, R.S.C., 1985, c. O-7, s. 1; S.C. 1992, c. 35, s. 2, from which the provisions of Part II (Petroleum Resources) and Part III (Petroleum Operations) of the Accord Acts were drawn.

R.S.C. 1985 , c. P-13, as rep. by S.C. 1999, c. 31, s. 257.

Supra note 3.

In Newfoundland, for example, the Atlantic Accord created a structure of joint governmental decisionmaking that protected an equal role for the Newfoundland government. The core technical material was largely borrowed from the then-new federal legislation, with a joint board created for administrative purposes. While this structure met its initial goals, from day one it began to lose its status as a single offshore regulatory window, and the difficulty in obtaining joint amendments to regulations saw a trend for federal departments to bypass the board system. In effect, the Accord regulations have not been overhauled since implementation and are now in many cases at variance with best regulatory practices worldwide. The global reality is that regulatory inefficiency downgrades the development potential of an oil and gas prospect. As technology has advanced, project engineering and design has long since 
independent joint federal-provincial Offshore Boards, the Canada-Newfoundland Offshore Petroleum Board (C-NOPB) and the Canada Nova Scotia Offshore Petroleum Board (CNSOPB) (collectively the Offshore Boards), each with an equal number of federal and provincial appointees and a jointly selected chair. "I The Offshore Boards award exploration licences, significant discovery licences and production licences. They manage a registry system for these rights. They review development plans, ${ }^{112}$ environmental impact statements and local benefits plans, and impose design, safety and environmental monitoring requirements. They grant work authorizations and issue operating licences necessary for oil and gas activities to occur in the offshore areas. The Offshore Boards regulate offshore exploration, development, completion, production, operation and abandonment activities, as well as health, safety, conservation and environmental protection matters. They monitor offshore operations in the areas of safety, environmental protection, resource management and industrial benefits.

The Offshore Boards operate autonomously in making decisions other than "fundamental decisions" which, subject to various overrides and vetoes, require the consent of both the federal and provincial energy ministers. Fundamental decisions include the approval of development plans, the issuance of cease orders on operations due to serious environmental or social problems, calling for bids to explore, issuing exploration licences and the cancellation of licences for non-compliance. ${ }^{113}$ Although the Offshore Boards are generally responsible for management in the first instance, governments have retained a degree of scrutiny and control through provisions for ministerial directives and consultation.

While the Atlantic Accord regulatory regime has held up quite well over fifteen years of application, several areas have emerged which may be ripe for reconsideration. Several important areas have been affected by subsequent legislation, case law or government trends, or have been shown by experience to be in need of review and revision. ${ }^{114}$

surpassed existing regulatory standards with, for example, Hibernia being required to obtain in excess of 350 regulatory equivalency rulings to permit its more advanced design to be used. Similar situations exist with the Sable and Terra Nova projects, and are currently being experienced with White Rose. While government and boards defend their actions and assert that rapid moves are underway towards more current industry practices, as a practical matter the existing procedural morass fails to advance environmental protection or safety to current international practices and impedes investment decisions. The complexity of the current east coast regulatory regime is reflected in the Regulatory Roadmaps Project, a project jointly undertaken by the Atlantic Canada Petroleum Institute and Erlandson \& Associates Consultants of Victoria, British Columbia, which has prepared comprehensive guides to the regulatory approval process for offshore oil and gas exploration and production in Atlantic Canada and in the north. These guides are available online: <www.oilandgasguides.com>.

The C-NOPB consists of seven members chaired by a combined Chair and CEO, and the C-NSOPB is a five-member board with a separate Chair and CEO. Civil servants are allowed to sit on the CNSOPB but not on the C-NOPB.

112 An offshore project cannot proceed without filing a development plan, dealing with a myriad of technical issues, such as estimated field reserves, method of field development, production rates, transportation, environmental protection, and having it approved by the relevant board after the public hearing process. Development approvals are granted subject to various terms and conditions that can impact upon project economics and operational viability.

Newfoundland Act, supra note 3, ss. 56, 58; Nova Scotia, supra note 3, ss. 59, 60-61; Newfoundland, supra note 3, ss. 57-58.

114 The Offshore Boards have run into problems with overlapping jurisdiction, primarily with fisheries, environment, and the NEB. See the Draft Memorandum of Understanding between the C-NSOPB and the federal Department of Fisheries (May 2001), which proposes a regime to ensure effective co- 


\section{B. REgULATORY FLEXIBILITY AND ACCOUNTABILITY}

The creation of the Offshore Boards shifted the offshore decision-making process away from each level of government to a separate entity, while at the same time implementing the reduction of discretionary administrative power. This is represented by the shift in regulatory philosophy from the Canada Oil and Gas Act, ${ }^{15}$ with its high level of bureaucratic discretion, to the approach taken in the Canadian Petroleum Resources Act ${ }^{116}$ - creating instead more defined objective criteria and processes by which decisions are made.

At the same time, however, the delegation of decision-making authority to the Offshore Boards separates decision-making from political accountability in such significant matters as local benefits and environment, and creates a rigid regulatory infrastructure requiring each level of government to act in tandem in effecting changes. Under the Accord Acts, ${ }^{117}$ for example, each level of government has agreed not to amend its Implementation Act ${ }^{118}$ without the consent of the other. Similarly, the proclamation of regulations requires the agreement of each level of government.

\section{REVENUE- VERSUS BENEFITS-BASEd REgULATION}

One threshold issue which must be addressed in establishing a regulatory regime for west coast offshore oil and gas is a choice between a revenue-based and a benefits-based regulatory model. ${ }^{119}$ The former approach emphasizes resource revenues and royalties, and the latter emphasizes local employment and economic activity.

ordination of planning, work and activities between the C-NSOPB and the Department of Fisheries and Oceans, online: <www.cnsopb.ns.ca/Environment/environment.html>. The respective jurisdictions of departments, agencies, boards and, in a separate way Aboriginal people, depend on applicable constitutional principles and the particular drafting of particular federal and provincial statutes. Great care should be taken to integrate as far as possible within a single strategy for moving forward in the offshore all those mandated under our law to play a role in the development of offshore resources.

Supra note 107.

Ibid.

Supra note 3.

Ibid.

Until the Supreme Court decision in the Hibernia Reference, Newfoundland had pursued a parallel track of offshore regulation to the federal government, focusing on job creation and local benefits issues. The logic of this focus in Newfoundland's case was plain: without a favourable ruling on property rights no royalty stream could be obtained and a local job creation bias provided immediate impact. Given the clawback provisions of the equalization program, monies spent by developers on jobs often had a greater positive impact on government revenues than direct cash flow to government. Further, a developed infrastructure with a trained local workforce would be a powerful incentive to companies to stay in the province, rather than site their operations elsewhere if the litigation result ultimately favoured the federal government. When the Accord legislation was formulated it maintained this benefits bias, still largely more beneficial to Atlantic governments than a revenue stream. Subsidies were used to induce industry to undertake activities in a manner that generated high levels of local employment and industrial benefits - for example, the federal PIP grants in the 1980s and federal support of the Hibernia Project in the 1990s. Specifically, loan guarantees and credits were given in return for commitments to build modules in Newfoundland. 


\section{ALTERNATIVE APPROACHES}

The Accord Acts ${ }^{120}$ encourage the employment of local workers, local goods and local services. Before the Offshore Boards can approve a project development plan or authorize any work in the offshore, as a statutory requirement the operator must submit and have approved a benefits plan that sets out their plans for hiring local labour and engaging local businesses in supplying goods and services, as well as targets for education, training and research support. ${ }^{121} \mathrm{~A}$ benefits plan is the plan submitted by the operator of a proposed offshore oil and gas project for employing Canadians, in particular the labour force of the province, and for giving provincial and other Canadian suppliers of goods and services "a full and fair opportunity to participate on a competitive basis" in each component of project construction and operation. ${ }^{122}$ After approving a benefits plan and a development plan, the Offshore Board may issue a work authorization and an offshore project may then proceed. ${ }^{123}$

Norway has similarly used a strongly interventionist approach to slow intentionally the pace of development and to maximize opportunities for local involvement and local benefits. This approach nurtured the growth of a fully integrated indigenous oil sector in Norway through partnering, state intervention and technology transfer. The slow pace of development permitted the Norwegian supply sector to develop its capacity to meet project supply needs, thereby extending the life and maximizing the value of the oil sector beyond the life of Norwegian oil reserves.

By way of contrast, in the United Kingdom the regulatory approach has been largely one of maximizing government revenue and expediting development in part to resolve balance of payment problems. The effect of relying on what is essentially a revenue-based model in the United Kingdom has been a heavy reliance on foreign companies, with few opportunities for domestic U.K. suppliers to develop offshore capacity. This has decreased the direct benefits of offshore projects to the local economy, and has ultimately limited the ability of U.K. firms to compete internationally. To this day few U.K. firms participate significantly in offshore development at the global level. ${ }^{124}$

Practically speaking, it is hard to envisage the British Columbia government achieving sufficient political support for the lifting of the offshore moratorium without implementing a policy of extracting significant local benefits for Prince Rupert and other coastal communities and Aboriginal interest groups. However, from a provincial political perspective the desire to lift the moratorium is being driven principally from a revenue perspective and by the seemingly insatiable needs of modern governments for new and expanded revenue bases.

Supra note 3.

Nova Scotia, supra note 3, s. 45(ii); Newfoundland, supra note 3, s. 45(ii). Note that the Offshore Boards may waive the requirement for a benefits plan (though in Nova Scotia only with the consent of the federal and provincial ministers).

Nova Scotia, ibid., s. 45(i); Newfoundland, ibid. s. 45(i).

Nova Scotia, ibid., ss. 142(i), 143(i); Newfoundland, ibid., ss. 138(i), 139(i).

For a discussion, see British Columbia Offshore Oil and Gas Technology Update, supra note 17 at 152. 
Moreover, the increasingly global and extremely mobile nature of the modern offshore drilling industry severely limits the scope for imposing a significant local benefits program on west coast offshore oil and gas development. Seismic surveys and exploration drilling are now typically carried out using expensive and highly mobile seismic vessels, drilling rigs and supply/support vessels manufactured in existing technologically-advanced facilities in other countries and owned and operated by specialist multinational companies that provide their services internationally on a contractual basis. The work is short-term and specialized, limiting opportunities for local involvement. ${ }^{125}$ Improved three-dimensional seismic technology has increased drilling success rates, meaning that fewer exploratory wells need be drilled. Both the maturing of the offshore industry and the range of international exploration opportunities worldwide means that local governments have very limited scope for imposing local benefit requirements, thereby reducing the international competitiveness of their local offshore projects. Consequently, the Offshore Update concludes that, "It is neither practical nor sensible to try developing local ownership of seismic, drilling or support equipment or to have locals become senior seismic or drilling crew." ${ }^{26}$ Local participation will typically be limited to providing labour, warehouse, office, residential and hotel accommodation and the provision of environmental, catering, transportation and professional services.

Similarly, at the development stage there has been a fundamental shift in offshore technologies. Each producing field has been developed with a different technical approach. Sable is a gas field, developed with a jack-up structure and pipeline transportation. Phase one cost approximately two billion dollars, and phase 2 , now in development, is forecast to cost an additional 600 million dollars. Hibernia used a gravity base system, with an initial capital cost of six billion dollars not counting drilling operations. Terra Nova is a ship shape floating production system with a capital cost of 2.8 million dollars. Both Hibernia and Terra Nova use tankers for oil transportation. Historically, production equipment consisted primarily of steel or concrete platforms resting on the seabed, containing drilling and processing facilities and associated accommodations. Such structures were constructed locally at locations such as Bull Arm, Newfoundland; Ardersier, Scotland; and Stravanger, Norway. More recently, there has been an increasing reliance on floating production, storage and off-loading systems (FPSOs): tension key platforms (TLPs), submersibles, semi-submersibles, spars, truss-spars, single column floaters (SCFs) and drill ships, which can be fabricated in technologically specialized yards internationally and then transported to the well-head for installation. For example, the FPSO hull used in Newfoundland's Terra Nova field is being built in South Korea, and an FPSO built entirely in international shipyards was proposed for the White Rose Project. ${ }^{127}$ Although design, fabrication and assembly work may be undertaken locally, it makes little sense to require that technologically sophisticated components such as hulls, spars, tension legs, and sub-sea completion be built locally for a single field development. Oil and gas can now be separated down hull and underwater from associated condensates,

125 A seismic program will typically be carried out by an international contractor and may last only a few weeks using a crew of twenty or thirty. A single well-drilling program can be completed in three or four months using a rig manned with forty to fifty personnel.

126. Supra note 17 at 142.

127 Development expenditures for Sable and Terra Nova were each about a third of the size of those for Hibernia. Approximately 800 workers are employed on the Hibernia Platform, 400 at Terra Nova and 840 at the Sable Project. 
eliminating the need for topside separation and stabilization facilities. Similarly, offshore pipelines have limited local benefits other than pipe-coating work for a short period, since specialized pipe-laying vessels are imported from the international market. ${ }^{128}$

On the other hand, unlike the situation in either Newfoundland or Nova Scotia, British Columbia already has a substantial onshore oil and gas industry which directly and indirectly employs over 15,000 individuals and which, last year, contributed 1.8 billion dollars to provincial revenues. British Columbia also has a significant high-tech ocean technology sector which produces ships, outfitting, engines, pipes, electronic navigation charts, navigation systems, underwater sensors, advanced marine acoustics, marine communications technology, underwater sensors and advanced radar technology for domestic and export markets. Development of the British Columbia offshore area could be a driver for a renewed marine engineering and construction sector in the province, and would increase the demand for services such as ocean charting, sea-floor mapping, the acquisition and interpretation of seismic data and environmental monitoring and assessment of marine ecosystems.

\section{THRESHOLD ISSUES}

Two critical threshold issues are the legitimacy of local benefit requirements under the mobility rights guarantees of s. 6(2)(b) of the Canadian Charter of Rights and Freedoms, ${ }^{129}$ and their legitimacy under the rules of free trade pursuant to the North American Free Trade Agreement. ${ }^{130}$

Under s. 6(4) of the Charter, employment preferences are expressly permitted as a means of addressing regional disparity:

Subsections (2) and (3) do not preclude any law, program or activity that has as its object the amelioration in a province of conditions of individuals in that province who are socially or economically disadvantaged if the rate of employment in that province is below the rate of employment in Canada. ${ }^{131}$

Under NAFTA, the existing Canada-Newfoundland and Canada-Nova Scotia benefits provisions are grandfathered under Annex $I^{132}$ to the Agreement. These exception provisions grandfather provisions in the Accord Acts, ${ }^{133}$ which require benefit plans, the establishment of local offices, technology transfers and local research and training programs from the prohibitions on performance requirements and the requirements for local presence contained in Articles 1106 and 1205 respectively of $N A F T A .{ }^{134}$ Express provision was made in Annex I to exempt similar provisions enacted to implement the Yukon Oil and Gas Accord

128 See British Columbia Offshore Oil and Gas Technology Update, supra note 17 at 145.

12. Part I of the Constitution Act, 1982, being Schedule B to the Canada Act, 1982 (U.K.), 1982, c. 11 [Charter].

130) S.C. 1993, c. 44 [NAFTA].

131 Supra note 129.

132 Supra note 130.

133 Supra note 3.

134 Supra note 130. 
Implementation $A c t^{135}$ and the Northwest Territories Oil and Gas Accord..$^{136}$ Unfortunately, no similar provision was made for an eventual Pacific Accord.

The exceptions period under $N A F T A^{137}$ has expired, and it may be very difficult to achieve a similar exception for any eventual Canada-British Columbia benefits program. It may, however, be possible to do so in the context of overall Canada-United States discussions on a continental energy policy. Also, the existing Annex I exempts benefits plans imposed by the federal Minister of Energy, Mines and Resources under the Canada Oil and Gas Operations Act. ${ }^{138}$ Therefore, it may be possible to extend the benefits of the NAFTA ${ }^{139}$ exceptions to offshore local benefits programs in British Columbia through application of the federal statute, although the benefits provisions of the Canada Oil and Gas Operations Act ${ }^{140}$ are not as broad as those contained in the existing Accord Acts. ${ }^{141}$

\section{LESSONS FROM THE EAST COAST}

The offshore petroleum activities on the east coast, aided by local benefits requirements, have generally expanded and diversified Newfoundland and Nova Scotia business and research capacities, with local companies, universities and research institutions now marketing their oil-related experience and expertise internationally. ${ }^{142}$

Nonetheless, experience and case law related to the Canadian east coast offshore shows that the regulatory benefits regimes established by the Accord Acts ${ }^{143}$ are flawed in some fairly major ways. On the operational side, the benefits enforcement mechanism is unwieldy; the remedy for failure to comply even with a small component of a project's approved benefits plan is for the Offshore Boards to revoke or suspend the project's work authorization, resulting in the project grinding to a halt. On the policy side, it is perhaps time to consider whether the province alone should administer and enforce benefits rules. The province is most keenly affected by, and therefore most interested in, achieving maximum benefits. Just as the Accord Acts ${ }^{144}$ apply the same royalty scheme to the offshore that would apply if the resource were located onshore, perhaps local benefits should be administered for the offshore in the same way they would be administered if a project were located onshore.

\section{LOCAL BENEFITS ENFORCEMENT}

Each of the current provincial $A c c o r d A c t{ }^{145}$ require the mandatory filing of benefit plans outlining the proposed means of adhering to the local benefits principles outlined in the legislation and provide that the local benefits plan must be approved before any development

S.C. 1998, c. 5 [Yukon Oil and Gas Accord].

The Accord was never concluded; see supra note 100.

Supra note 130.

Supra note 107.

Supra note 130.

Supra note 107.

Supra note 3.

Offshore Update, supra note 17.

Supra note 3.

Ibid.

Ibid. 
plan is approved and work or activity in the offshore begins. The benefit plan must outline how the project will be structured so as to provide Canadians, and particularly provincial residents, with a full and fair opportunity to participate in the project. The plan must include employment of Canadians, particularly members of the provincial labour force, by giving them first consideration for training and employment in the work program. The plan must also provide manufacturers, consultants, contractors and service companies in the province and other parts of Canada "with a full and fair opportunity to participate on a competitive basis in the supply of goods and services" used in any proposed offshore work or activity by providing them with first consideration where their goods or services are competitive in terms of fair market price, quality and delivery.

Full and fair opportunity effectively means that operators must adhere to an open, fair and predictable procurement policy that involves notice, pre-qualification, tendering and contract award. If a sufficient number of qualified provincial bidders are available to assume competitive bidding, the bid list must be limited to local companies; and if bids essentially equal in terms of fair market price, quality and delivery are tendered, the local company must be selected. The experience in the maritimes has been that the Offshore Boards have taken an interventionist approach in imposing and monitoring local benefits conditions. The operator of the offshore project must establish an office in the province where appropriate levels of decision-making are to take place and must provide a program to promote education and training, as well as research and development relating to the offshore resource activities, in the province. If the Offshore Boards so require, a plan to ensure that disadvantaged individuals or groups have access to training and employment opportunities must also be established. The benefits provisions of the existing Accord Acts ${ }^{146}$ have been the basis for litigation by unsuccessful bidders alleging that they did not receive a full and fair opportunity to bid and secure contracts.

The Offshore Boards' sole benefits plan enforcement tool is contained in Nova Scotia Act s. $142(5)^{147}$ and Newfoundland Act s. $138(5):{ }^{148}$

(5) The Board may suspend or revoke an operating licence or an authorization for failure to comply with, contravention of or default in respect of

(a)

a requirement, approval, fee or deposit, subject to which the licence or authorization was issued ...

Suspension or revocation of a work authorization is an unwieldy and blunt instrument for enforcing an operator's benefits commitments, especially since the result of invoking the remedy could be the permanent or temporary cessation of all project work, thereby effectively eliminating local benefits altogether. Accordingly, when designing the west coast offshore regulatory regime, consideration should be given to expanding the available benefits enforcement remedies to include benefits exchanges, alternatives and replacements, and penalties. 
Another problem which has arisen on the east coast is the identity of those persons entitled to enforce benefits commitments. In City of St. John's v. Canada-Newfoundland Offshore Petroleum Board ${ }^{149}$ St. John's tried to force the C-NOPB to enforce a benefit commitment made by Petro-Canada as operator of the Terra Nova Project. The Terra Nova benefits plan had included a "best efforts" commitment to relocate engineering and procurement activities to the province of Newfoundland. In January 1998. the C-NOPB approved the Terra Nova benefits plan subject to conditions. Condition 1 required that, "As soon as practicable after Project Sanction, the Proponent relocate engineering and procurement activities for the Project to Newfoundland."

Within a very short time after its benefit plan was approved, Petro-Canada advised the CNOPB that compliance with Condition 1 would cost 30 to 40 million dollars and proposed, but then withdrew, a compromise proposal. Petro-Canada concluded that there was little value in relocating the engineering effort. The C-NOPB reluctantly decided to interpret Condition 1 as a "best efforts" commitment and concluded that the operator had used its best efforts to relocate the engineering services to St. John's and therefore had satisfied this condition.

St. John's considered that it would have been a primary beneficiary of the relocation of engineering services to Newfoundland, and upon hearing that this would not happen, commenced an action for a declaration that Petro-Canada move its engineering and procurement activities to Newfoundland and for an order of mandamus requiring the $\mathrm{C}$ NOPB to enforce Condition 1.

Although the Court found that Petro-Canada did not in fact comply with Condition 1, it also found that St. John's did not have the capacity or the standing to sue, and it therefore dismissed the action. ${ }^{150}$ In case he was wrong, Orsborn J. went on to find that the city was not in any event entitled to an order of mandamus. The Court concluded that,

Inherent in the City's request for relief is the assumption that the Board actually has the authority to force the Proponent to move its engineering activities to Newfoundland. This assumption may not be well-founded. The Board does possess certain powers of enforcement - notably the power to revoke a licence or authorization. But whether its statutory authority extends to a direct order to carry on work in a certain location is an unanswered question. The ability to revoke a licence may provide opportunities to achieve a particular outcome through influence and persuasion, but the actual order of the Board sought by the City may not be within the authority of the Board.

The legislation does not impose on the Board a statutory duty to enforce Condition No. 1. The enforcement authority of the Board is discretionary. Accordingly, notwithstanding the Proponent's non-compliance with the Conditions, the Board owes no statutory duty to the City to enforce the Condition. The City is not entitled to an order in the nature of mandamus. ${ }^{151}$ 
A year later, A.M.O. Containers Limited (A.M.O.), which had not been invited to tender on a contract to supply offshore containers to the Hibernia Project, sued the Government of Canada, the Government of Newfoundland, the C-NOPB, the Hibernia Management and Development Company Limited and the two companies down the contracting chain that had failed to invite A.M.O. to tender. ${ }^{152}$ The province applied to have A.M.O.'s claim against it set aside for disclosing no reasonable cause of action. The province was successful.

Justice Orsborn cited with approval these excerpts from his earlier decision in City of St. John's:

Clearly, it was the intent of both governments that issues relating to economic benefits would be left to the Board, subject only to joint direction from the governments. In other words, ensuring that the appropriate economic benefits are delivered to Newfoundland and Canada is a responsibility given to the Board by the legislation, subject to any overriding joint directive of both governments.

As a matter of public policy both governments ... have left enforcement issues to the discretion of the Board. $^{153}$

It is hard to find fault in these decisions, but it is also hard to dismiss out of hand the concerns of the respective plaintiffs. Neither a municipality which stood to benefit directly from a condition imposed by the Offshore Boards, nor a local manufacturer of goods who was not invited to tender, has any legal recourse to enforce the benefits commitments of project operators.

British Columbia and the federal government might review the Accord Acts ${ }^{154}$ and the above cases and consider, as recommended above, the expansion of remedies the Offshore Boards have to enforce benefits commitments. To be able only to suspend or revoke a work authorization is clearly insufficient. A.M.O. ${ }^{155}$ provides a particular demonstration of the inappropriateness of the heavy remedy, which would have been to suspend all work at Hibernia, which had at that time been producing oil for two years, because a sub-contractor had failed to invite a local supplier to tender on a sub-contract. It is also recommended that the governments of British Columbia and Canada consider giving third parties the right to enforce benefits commitments of project operators.

\section{LOCAL ADMINISTRATION OF LOCAL BENEFITS}

British Columbia and the federal government should consider transferring the administration and enforcement of local benefits to the province alone. The provincial government has direct access to the best information concerning the abilities and capacities of workers, manufacturers, service suppliers and consultants available in the province. It has direct access to the best information concerning education and training facilities and opportunities. It presumably has the greatest interest in securing for its residents first 
consideration in the supply of goods and services, provided that they are competitive in terms of fair market price, quality and delivery. Something is clearly askew when, as happened in A.M.O. ${ }^{156}$ a province is forced to go to court to have dismissed a claim by one of its resident companies that the tendering process for offshore work has failed to serve the interests of the people of the province.

There are also drawbacks to transferring benefits administration solely to the province. The province does not have access to the Offshore Board's detailed, up-to-date knowledge of the offshore oil and gas industry, and can therefore not evaluate as well the opportunities for offshore work. The Offshore Boards are, however, joint federal-provincial boards, and with good lines of communication this drawback should be easily overcome. Perhaps more significantly, the province would not be expected to enforce benefits rights of Canadians who reside outside the province as diligently as it would those of its own residents. It is surmised that Canadian workers and suppliers outside the host province benefit very little from existing benefits regulations, and that the mobility rights in the Charter, ${ }^{157}$ newly implemented and untested when the Accord Acts ${ }^{158}$ were negotiated, now provide adequate cross-Canada protection from overly aggressive provincial measures to retain benefits.

\section{Performance-based Versus Prescriptive Regulation}

\section{BACKGROUND}

There has been a distinct shift in regulatory philosophies in the fifteen years since the Accord Acts ${ }^{159}$ regimes were implemented, as reflected in the movement away from prescriptive and towards more result-oriented regulatory models.

A defining event in this shift was the sinking of the Ocean Ranger off the Newfoundland coast in February 1982 and the regulatory responses to that disaster. The sad truth is that it takes a disaster to change the law at least to make significant changes in the regulation of health, safety and environmental matters. Unfortunately, many of the offshore regulations put in place in reaction to the disaster constitute a top-down compliance regime based on thencurrent design models, now frozen in time. This model has not kept up with the huge changes in technology and knowledge and is not the current design model. The result is a level of frustration with the nature and detail of regulations and rules which are out of step with current state-of-the-art technology.

At the time of the sinking of the Ocean Ranger, Canadian offshore oil and gas law was in federal-provincial jurisdictional chaos. Only certain federal laws, and no provincial laws, applied beyond the territorial sea. International law of the sea conventions were approaching completion but they had not been ratified, nor had their principles been incorporated into domestic law. Accordingly, the thrust of the Ocean Ranger report recommendation was to 
get a more comprehensive body of law in force in the offshore area endorsing regulationmaking through the setting of principles, performance standards and other criteria.

Recommendation 81 of the 1984 Report of the Royal Commission on the Ocean Ranger Marine Disaster was as follows:

It is therefore recommended:

81. That

(a) more extensive regulations and guidance notes be developed.

(b) insofar as it is practical, regulations be framed in terms of principles, performance standards and criteria, which, supplemented with a comprehensive body of guidance notes, are made available in a consolidated form. ${ }^{160}$

Performance-based regulation in the offshore oil and gas context sets out safety, environmental, conservation, production and other standards to which an operator must conform, but does not prescribe how those standards are to be met. The operator must submit, for the approval of the regulator, a plan demonstrating how the standards will be met and how the operator's performance will be monitored.

Lord Cullen's Report of the Public Inquiry into the Piper Alpha Disaster ${ }^{161}$ is often credited as the source document for modern offshore oil and gas performance-based regulation. The Piper Alpha was a production platform which exploded and burned in the U.K. sector of the North Sea on 6 July 1988. Lord Cullen's Executive Summary contains the following reference to performance-based regulation:

\begin{abstract}
1.21 In Chapter 21 I set out my general findings in regard to the existing safety regulations and guidance relating to them. Many regulations are unduly restrictive in that they are of the type which impose "solutions" rather than "objectives" and are out-of-date in relation to technological advances. Guidance notes are expressed, or at any rate lend themselves to interpretation, in such a way as to discourage alternatives. There is a danger that compliance takes precedence over wider safety considerations; and that sound innovations are discouraged. The principal regulations should take the form of requiring stated objectives to be met. Guidance notes should give non-mandatory advice. On the other hand I accept that in regard to certain matters it will continue to be essential that detailed measures are prescribed. ${ }^{162}$
\end{abstract}

As Lord Cullen stated in the body of his report,

21.67 I am entirely satisfied that the principal regulations in regard to offshore safety should take the form of requiring that stated objectives are to be met rather than prescribing that detailed measures are to be taken. In relation to such regulations guidance notes should give non-mandatory advice on one or more methods of achieving such objectives without prescribing any particular method as a minimum or as the measure to be taken in default of an acceptable alternative. On these points I endorse the recommendations of the Burgoyne Marine Disaster, Report Two: Safety Offshore Eastern Canada (Ottawa: Canadian Government Publishing Centre, 1985). Majesty's Stationery Office, 1990) [Piper Alpha Report]. 
Committee at 6.15 and 6.17. However, I accept that there will be a continuing need for some regulations which prescribe detailed measures.

21.70 Operators should be encouraged to specify standards to be used by the company with a view to demonstrating compliance with goal-setting regulations. Thus in the case of a given installation operators may demonstrate compliance by reference to such standards, the terms of guidance notes and what is shown by a safety assessment or a combination of one or more of such methods. ${ }^{163}$

Performance-based regulation puts the responsibility to develop solutions and to constantly improve upon those solutions on industry. The industry creates operations and environmental risk in the first place and performance-based regulation makes the creator of those risks responsible for controlling them. The regulator usually sets the standard based on a "Best Available Safest Technology" standard, or perhaps a prescriptive middle-ground standard of fixed levels (for example, "x parts per million"). The operator produces a safety, environmental protection or other plan to meet the standards. The regulator evaluates the plan and rejects, approves or suggests modifications to the plan. The operator monitors the activities subject to the plan and reports to the regulator periodically for normal activities and immediately when there is trouble. The regulator conducts spot audits. The operator's plan is regularly updated to incorporate technological change, lessons from experience, greater efficiencies and other improvements.

The goal-setting or performance-based model for regulation differs from the "prescriptive" model, which sets out in detail exactly what an operator must do to comply with the regulation. The main virtue of prescriptive regulation is certainty, but certainty has a dark side. The certainty of detailed prescriptive regulations cannot accommodate new technology or changing standards. This is a particularly serious problem in times, like the present, of constant and rapid technological advancement, and is made even more serious by the twoto five-year gestation period required for the enactment of federal-provincial regulations. The Offshore Update concluded as follows: "Given the rapid advances in the technology of offshore oil and gas exploration and production and the complexity of the operations, regulatory agencies should avoid excessive reliance on prescriptive regulations. Such an approach could restrict innovative solutions." 164

As well, prescriptive regulation creates and fosters a compliance mentality in the oil industry. A compliance mentality, and the prescriptive regime which causes it, tend to freeze solution-seeking and the improvement cycle at the point of technology reflected in a regulation - a regulation which may be obsolete well before it is promulgated. 


\section{REgULATION UNDER THE ACCORD ACTS}

The regulations under the $A c c o r d A c t{ }^{165}$ contain both performance-based and prescriptive components but has been criticized, in general, as being overly prescriptive. Jacques Whitford Environment Limited, for example, makes the following comment:

The Eastern Canadian offshore regulations are heavily prescriptive which can place a significant cost burden on potential offshore activities. With the advances in the technology of offshore investigations, drilling and production, there is a significant opportunity to use a results oriented, review and approval process to ensure the highest economic benefits while ensuring that the potential for environmental and safety risks are adequately controlled. ${ }^{166}$

An example of performance-based regulation is s. 51(1) of both the Nova Scotia and the Newfoundland Offshore Area Petroleum Production and Conservation Regulations:

An operator shall develop and submit to the Chief Safety Officer a safety plan that provides for all matters related to the safety and health of personnel and the integrity of an installation and that includes

(a) a statement of the operator's safety management policy and a description of the procedures established to ensure its effectiveness;

(b) a summary of the results of all studies undertaken to identify hazards and to assess risks to the installation and means to mitigate those risks;

(c) a description of the features incorporated in the design of the installation and of the equipment provided to eliminate hazards and reduce risks to the occupational safety and health of personnel;

(d) a description of the procedures established and the manuals provided for the safe operation and maintenance of the installation;

(e) the standards adopted for the training and qualifications of personnel;

(f) a description of the command structure on the installation and for the operator's onshore base and their relationship to each other;

(g) contingency plans for response to and mitigation of accidental events affecting the safety of persons on board, or the integrity of, the installation;

(h) a description of the physical environmental monitoring equipment; and

(i) the distance from the production installation, at which the standby vessel referred to in section 56 shall remain during normal operations. ${ }^{167}$

An example of prescriptive regulation is s. 53(1) of those same regulations:

Subject to subsection (3), an operator shall ensure that

(a) the components of the safety system of a production installation are tested, and malfunctions of the system are recorded in accordance with API RP 14C Recommended Practice for Analysis, Design, Installation and Testing of Basic Surface Safety Systems for Offshore Production Platforms;

Supra note 3.

Supra note 17 at 172.

See N.S. Reg. 95/190; Nfld. Reg. 78/99. In an attempt to make prescriptive regulations more flexible, the Accord Acts allow the Chief Safety Officer and Chief Conservation Officer to substitute alternate equipment, methods, measures or standards for their prescribed equivalents, provided that the existing standards of safety, environmental protection and conservation are maintained. This provision is a partial solution to the rigidity of prescriptive regulation. 
(b) every emergency shutdown station that forms part of the safety system is tested at least once every 30 days;

(c) at least once every month,

(i) every surface safety valve installed on a christmas tree is tested for function and for leakage,

(ii) every pressure sensor is tested,

(iii) every liquid level control device is tested by activating the sensor for the device,

(iv) every check valve installed in the piping system is tested for leakage,

(v) every automatic inlet shutdown valve on a vessel or compressor that is actuated by a sensor is tested,

(vi) every shutdown valve that is located in a liquid discharge line from a vessel and is actuated by a low-level sensor is tested, and

(vii) every shutdown valve installed on a production riser and associated manifold is tested;

(d) every shutdown control installed on a compressor that is actuated by temperature sensors is tested at least once every six months;

(e) every pressure-relief valve is tested at least once every 12 months, either through bench-testing or, where possible, in situ testing using an external pressure source; and

(f) all fire, hydrogen sulphide and gas detection systems are tested for operation every three months and recalibrated if necessary.

\section{THE SHIFT TOWARDS PERFORMANCE-BASED REgulation}

The move toward performance-based regulation beginning, at least in the Canadian east coast offshore, began with the recommendations of the Ocean Ranger inquiry, continued and was accelerated by the Piper Alpha Report, and has continued to gain momentum. In 1993 the Government of Canada's publication Responsive Regulation in Canada endorsed performance-based regulation:

3.2 Where feasible, regulations should be expressed as functional outcome or performance objectives rather than detailed specification of the means of compliance. ${ }^{168}$

At a conference in St. John's, Newfoundland in December 2000, expert representatives from Canada, Norway, the Netherlands, the United States and the United Kingdom all reaffirmed their governments' commitment to performance-based regulation, particularly in the areas of safety, environmental protection and resource conservation.

In recognition of this important trend in the management and regulation of offshore activities, British Columbia-Canada negotiators should consider incorporating a number of provisions into their equivalent to the section in the legislation authorizing the making of safety, environmental protection, and resource production and conservation regulations. ${ }^{169}$ These provisions might include specific authorization for the making of performance-based regulations, the criteria for plans to be prepared by the operator, the kinds of standards which may be adopted, self-monitoring guidelines, and reporting and periodic reconsideration. 


\section{E. Royalties AND REvenue Sharing ${ }^{170}$}

The basic policy decision respecting a petroleum royalty regime for the British Columbia offshore area is the choice between generic or statutory royalties and negotiated or contractual royalties. A second policy choice is between implementing a gross and/or net royalty.

To date, the royalty regimes applicable to each of the offshore Atlantic petroleum fields in production have been contractual royalties negotiated on a project-by-project basis. The latest project to be approved, the White Rose Project, will be governed by a generic royalty regime which will be set out in provincial royalty regulations.

\section{OBJECTIVE IN DESIGNING AN OFFSHORE ROYALTY REGIME}

The royalty regime for the British Columbia offshore area should be designed to create a favourable economic environment for industry in the exploration for and sustained development of the offshore oil reserves, while at the same time ensuring that the provincial government receives a timely and fair share of the revenues and profits generated by the oil reserves.

Massive long-term investment is required to develop the potential petroleum reserves in the British Columbia offshore area. The recovery of this capital investment will be affected by uncertain factors, including the delay between exploration and production, the ultimate size and quality of the petroleum reserves, the actual cost of extraction and world commodity prices.

From the perspective of industry, the royalty and revenue-sharing regime must:

(i) provide certainty as to the amount of royalties that will be payable throughout the life cycle of the offshore petroleum project. At the early stages of exploration and prior to the outlay of substantial capital, industry will want to know the amount of royalties to be imposed. It will also want to know that the royalty regime cannot be easily amended by successor governments without consulting industry;

(ii) be highly profit-sensitive so as to adequately compensate industry for any extra costs associated with establishing the required infrastructure and for any special risks or costs encountered in the development of the offshore area, while at the same time fully capturing economic rents for governments; and

(iii) be integrated into the local benefit regimes and applicable provincial and federal taxation rules applicable to the offshore petroleum developments. This integration will provide industry with full knowledge of the fiscal costs associated with the project.

From the perspective of the provincial government, the royalty and revenue-sharing regime must: 
(i) provide for a fair royalty, taking into account the rate of depletion of the reserves, fluctuations in world commodity prices, technological advances and other factors which will impact on the net value of the petroleum reserves;

(ii) be competitive with royalty regimes in comparative offshore petroleum areas without underselling the resource owner's interests;

(iii) address the timing of receipt of royalties. In particular, the regime must balance the provincial government's desire to realize revenue as soon as possible after the commencement of production with the desire to maximize the amount of revenues received over the life span of the project;

(iv) not distort the profitability of marginal production, so that decisions by industry to increase, decrease or cease production will be based solely on market conditions and not on minimizing royalty costs; ${ }^{171}$

(v) provide for special royalties on any "super profits" which may be earned on any project at any given time; ${ }^{172}$ and

(vi) be transparent and easily understood by the public so that it is not only fair but is also perceived by the public to be a fair regime. This will better enable the regime to withstand the temptation of successor governments to amend the royalty structure for political gain.

\section{CHOICE OF ECONOMIC REGIME}

The choice between a gross or net royalty can impact the timing of receipt of revenues, the mix of revenues and other benefits derived by the provincial government from the offshore petroleum reserve.

\section{a. Gross Royalty}

A gross royalty is essentially a fixed royalty imposed on the gross value or revenue of production. Gross royalties are a variation on volume-based royalties which are a fixed levy on production volumes. Volume-based royalties are the traditional regime for onshore oil production. Such regimes have been modified to take into account fluctuations in price from the time of discovery to the time of production. ${ }^{173}$ Gross and volume-based royalties are earned regardless of the profitability of the project. Typically the rate at which such royalties are imposed is lower than the rate imposed on a profit or net revenue basis. Gross royalties are easy to determine, collect and enforce. The payment of such royalties typically commences at the start of production. Gross royalties are not sensitive to fluctuations in production costs or commodity prices, and can distort the underlying profitability of an offshore field. Accordingly, gross royalties will have an impact on decisions by the producers as to the rate, timing and volume of production. The results of these decisions may prevent the extraction of the maximum economic benefit of a particular field. 


\section{b. Net Royalty}

A net royalty, on the other hand, is imposed on profits as opposed to volume or gross revenues. The economic model for a net royalty regime is often called the "resource rent royalty" (RRR). ${ }^{174}$ Under an RRR the resource owner is entitled to a rent on ordinary profits and an enhanced rent on super-normal profits in a model which takes into account the risks and possible rewards of the particular resource extraction project without discouraging investment. Typically, an RRR will not provide the resource owner with any royalties until, and only if, the threshold costs have been recovered. The resource owner does not contribute capital to the project, but defers its contribution by crediting its share of the capital investment against profits. The RRR is determined on a project-by-project basis, and profit is based on revenue in excess of a threshold return on investment. This threshold should be enough to compensate the industry for both the capital invested and the risk associated with each offshore project. ${ }^{175}$

\section{c. Canadian Model}

The royalty model used in Canadian offshore and frontier oil production ${ }^{176}$ is a hybrid of a gross royalty up to a certain threshold, and an RRR-type royalty imposed on net profits once project costs have been recovered. This is meant to ensure an early royalty stream followed by an increased share of profits.

\section{CHOICE OF LEGAL REGIME}

A decision regarding the legal regime to be implemented by British Columbia will also require a choice between a negotiated or contractual regime specific to every project, or a generic or statutory regime that encompasses all of the new projects.

\section{a. Negotiated Regime}

A negotiated or contractual royalty is a project-specific royalty structure negotiated on an ad hoc basis between the provincial government and the producer. A negotiated contractual royalty can be fine-tuned to fit the particular project and the risks involved, taking into consideration the field's particular reservoir characteristics, anticipated production profile and projected cash flows. Royalty rates and cost-deduction rules can be customized to account for the project timing and economics, escalating from low pre-payout gross royalty rates to higher post-payout net profit royalty rates. Experience has proven that a drawback of negotiated contractual royalties is that several years and a huge commitment of resources is generally necessary to achieve their completion. ${ }^{177}$

A negotiated royalty is implemented through an agreement entered into between industry and either the provincial government or the body to which the negotiation of the agreement

Ibid. at 19.

Ibid. at 19-21.

Ibid. at 22, in reference to the Alberta Cold Lake Agreement.

The Government of Nova Scotia entered into five separate royalty agreements regarding the Sable Offshore Energy Project. 
is delegated. In theory, a negotiated contractual royalty affords industry some measure of protection against arbitrary royalty changes imposed by government in so much as any adverse changes to the royalty can be viewed as a breach of contract leading to compensation or litigation.

\section{b. Generic Regime}

A generic or statutory royalty regime differs in that it is a fixed royalty structure set out in statute for general application to all producers operating in a particular offshore area. A generic regime should be designed to have built-in adjustments for risk and profitability, including commodity prices, normal and exceptional costs and the marginal profitability of different reservoirs.

A statutory royalty regime, put in place prior to the exploratory stage of resource development, allows industry to make an up-front assessment of project economics and industry netbacks. A properly drafted generic royalty regime will be highly profit sensitive. It will allow for the deduction of all exploration, pre-development and developing, operating, marketing, transportation and decommissioning costs. These costs will be uplifted to allow for overhead costs, and will be tiered to increase when a risk-adjusted threshold rate of return is reached. The fiscal terms are to provide for a competitive rate of return for the owner and will allow investors to make a competitive, risk-adjusted return on invested capital.

The implementation of a generic offshore royalty regime will be beneficial in reducing the cost and time-frame in finalizing and executing royalty agreements. Generic royalty regimes will not necessarily be full and total replacements may be needed for specific negotiated agreements. ${ }^{178}$

There are significant drawbacks to generic or statutory royalty regimes, however. For instance, by virtue of their statutory nature, statutory royalties can be unilaterally amended or abrogated by legislative act when governments or the political environment change. With the benefit of hindsight, the government of the day may find that the revenue-sharing formula inherent in the generic royalty overcompensates industry and undercompensates the public purse.

In practice, statutory royalty regimes seem invariably to undercompensate the industry by systematically failing to permit the deduction of all fair and reasonable costs deductible in establishing an economic rate of return. At the same time, the regimes short-change the government by failing to account for the major impact on the timing of project returns by underestimating the impact of technological changes occurring over the lifetime of the project. 


\section{ATLANTIC EXPERIENCE - NEGOTIATED ROYALTY REGIMES}

Under both of the Accord Acts, ${ }^{179}$ the provincial governments are given control over the design of royalty structures. The basic scheme reserves a federal Crown royalty but provides that it is not applicable where a provincial royalty is applicable.

The federal Accord Acts ${ }^{180}$ incorporate by reference the applicable provincial royalty statutes: Newfoundland's Petroleum and Natural Gas Act ${ }^{181}$ and Nova Scotia's Offshore Petroleum Royalty Act. ${ }^{182}$ Both statutes permit the provincial minister to negotiate and enter into contractual royalty agreements. In addition, Nova Scotia has entered into a Royalty Collection and Administration Agreement ${ }^{183}$ with the federal government.

The principle of revenue-sharing established in the Accord Acts ${ }^{184}$ was that revenues from the offshore would belong to the province to the same extent as revenues from petroleumrelated activities on land. This includes enacting federal legislation to permit the provincial governments to establish and collect resource revenues, such as royalties and bonus payments, and to apply provincial taxes of general application in the offshore area, including sales and corporate income taxes. Revenue-sharing must be understood in the context of the equalization offset regimes contained in the existing Accord Acts, ${ }^{185}$ which have the effect of reducing equalization payments made to Newfoundland and Nova Scotia. Production royalties are paid to those provinces.

Unfortunately, the royalty regimes implemented by the $A c c o r d A c t{ }^{186}$ raise more technical questions than they answer. The federal government has essentially abandoned the legislative and regulatory field governing offshore royalties and is not involved in the negotiation and execution of contractual royalty agreements. Walter F. Muscoby, ${ }^{187}$ for example, has questioned the ability of the provincial minister to enter into Crown royalty agreements binding on the federal minister and whether the agreements can be entered into prior to the principals acquiring interests in production licences. Other questions are created by referential incorporation and delegation of powers.

In Nova Scotia and Newfoundland, the provincial governments used the powers granted to them by the federal government under the Accord Acts ${ }^{188}$ to enter into royalty

179) Supra note 3

180 Ibid.

181 R.S.N. 1990, c. P-10.

182 S.N.S. 1987, c. 9.

183 N.S. Reg. 71/99.

$184 \quad$ Supra note 3.

185 Ibid.

186 Ibid.

187 W.F. Muscoby, "Some Aspects of Royalty Agreements Under the Nova Scotia Offshore Petroleum Royalty Act" (Paper presented to the Canadian Petroleum Law Foundation, East Coast Seminar, 28-30 September 2000) [unpublished].

188 The initial agreement granting the province of Newfoundland power: Memorandum of Agreement between the Government of Canada and the Government of Newfoundland and Labrador on Offshore Oil and Gas Resource Management and Revenue Sharing (Atlantic Accord) (11 February 1985). In 1988, the federal government enacted the Newfoundland Act, supra note 3. This was done at the same time as the government of Newfoundland enacted the Canada-Newfoundland Atlantic Accord 
arrangements with respect to the Atlantic offshore energy projects. The royalty regimes for the first major Atlantic offshore oil projects were negotiated contractual royalties. These regimes were applied to Hibernia and Terra Nova in Newfoundland and Cohasset and Sable Island in Nova Scotia.

Both Newfoundland and Nova Scotia later adopted generic royalty regimes. ${ }^{189}$ These will be used for the most recent Atlantic projects, namely the Marquis project in Nova Scotia and the White Rose project in Newfoundland. ${ }^{190}$ The Newfoundland and Nova Scotia experiences with negotiated royalty regimes are instructive and demonstrate some of the strengths and weaknesses of such arrangements and the legislative framework in which the regimes have been enacted.

\section{a. Hibernia}

The Hibernia royalty regime is a project-specific regime that combines a statutory royalty and a negotiated royalty pursuant to an agreement entered into between the Newfoundland government and the Hibernia consortium in $1991 .^{191}$ The statutory royalty is a one percent per-barrel charge which can be credited against the contractual royalties payable. The original contractual regime provided for a gross revenue royalty of one percent to be increased by increments of one percent following the lapse of each eighteen-month period to a maximum of five percent. Following simple payout, the province is entitled to a net royalty of 30 percent and a supplementary royalty of 12.5 percent on revenues in excess of the reserve allowance. ${ }^{192}$ The net royalty is credited against the gross royalty. ${ }^{193}$ As of May 2002 , simple payout has not occurred and, therefore, no net royalties are being paid on Hibernia oil.

It took over a year to negotiate the Hibernia royalty agreement. The royalty agreement took into account certain special features of the Hibernia project. For example, the Hibernia

Implementation Newfoundland Act, R.S.N. 1990, c. C-2. This gives the province the power under the Petroleum and Natural Gas Act, supra note 181, to regulate royalties.

The initial agreement granting the province of Nova Scotia power: Memorandum of Agreement entitled "Canada-Nova Scotia Offshore Petroleum Resources Accord," between the Government of Canada and the Government of Nova Scotia (Nova Scotia Accord) (26 August 1986). In 1988 the Nova Scotia and federal governments enacted similar acts to those Newfoundland had enacted with the federal government. The federal government enacted the Nova Scotia Act, supra note 3 . This was done at the same time as the government of Nova Scotia enacted the Nova Scotia Act, ibid. This gives the province the power under the Offshore Petroleum Royalty Act, supra note 182, to regulate royalties.

Newfoundland announced its generic royalty regime on 13 June 1996; online: Government of Newfoundland < www.gov.nf.ca/releases/1996/mines\&en/0613n06.htm>. In July 1999 Nova Scotia put generic royalty regulations in place; online: Government of Nova Scotia <www.gov.ns.ca/ petro/documents/RoyaltyRegime.pdf $>$.

The White Rose project has been approved by the C-NOPB, and according to a representative of the Newfoundland Department of Mines and Energy, it will be based on the new Newfoundland generic regime. According to a representative of the Nova Scotia Petroleum Directorate, the final agreement has not yet been reached on the Marquis project; however, such agreement will be governed by the new generic regime.

19.3 The net royalty is paid on the excess of gross revenues over the return allowance, which is 15 percent for tier one, and 18 percent plus the long-term bond rate for the supplementary royalties. 
consortium was provided with loans guaranteed by the Government of Canada. In order to assist the consortium in meeting its obligations under the federally guaranteed loans, the gross royalty provisions contain an indexing clause which reduces the gross royalties payable to the province if crude oil prices sink below an established level while federal loans are outstanding. ${ }^{194}$ Furthermore, it is widely believed that the Newfoundland government agreed to accept the lower gross royalty in exchange for a commitment by the Hibernia consortium to use a gravity-based system (GBS), which would create more jobs and other collateral benefits for Newfoundland than would an alternate floating platform system.

Hibernia commenced oil production in 1997. In February 2000, the Hibernia Management and Development Corporation submitted an application to the C-NOPB to increase daily production from 150,000 to 200,000 barrels a day and to increase the annual production limit from 50 million to 66 million barrels. ${ }^{195}$ One of the rationales for the proposed increase in production was to take advantage of exceptionally high commodity prices which would have improved the initial rate of return on the project. ${ }^{196}$ Also, lower royalty rates are paid in the beginning period of production, so another benefit would arise if production was increased.

The C-NOPB held that the increase in annual production constituted an amendment to the Hibernia Development Plan and, as such, was a fundamental decision requiring notice to and consent of the federal and provincial governments. The provincial Minister of Mines and Energy indicated that Newfoundland would not accept the proposed increase in annual production on the basis that more oil would be taken from the field at a lower royalty rate and would thereby have a negative impact on the total amount of royalties to be received by the province over the life of the project. ${ }^{197}$

Following the negotiations between the Hibernia consortium and the provincial government, on 22 June 2000, the Newfoundland Department of Mines and Energy announced that an agreement had been entered into, in principle, to allow for an increase in Hibernia's annual rate of production. Under the agreement the province would receive higher royalty rates earlier and gross royalty rates would be tied to the rate of production and not simply to the passage of time. ${ }^{198}$ The production component of the royalty was described as an "add on" to the existing royalty regime.

M. Harrington et al., "Emerging Issues in East Coast Oil and Gas Development" (1997) 35 Alta. L. Rev. 269.

See the press release of the Canada-Newfoundland Offshore Petroleum Board (17 February 2000), online: Government of Newfoundland and Labrador <www.gov.nf.ca/releases/2000/mines\&en/ /0217n03.htm>.

M.R. Smith \& B.D. Neilson, "Offshore Oil and Gas: A Perspective on Exploration and Development of Offshore Petroleum and Natural Gas Resources in Eastern Canada" (2001) 13:1 CPTJ.

See the news release issued by Paul Dicks, Minister of Mines and Energy (10 April 2000), online: Government of Newfoundland and Labrador <www.gov.nf.ca/releases/2000/mines\&en/0410n02.htm>. See Government of Newfoundland and Labrador press release, online: Government of Newfoundland and Labrador <www.gov.nf.ca/releases/2000/mines\&en/0622n04.htm>. 
The contractual royalty was entered into between the Newfoundland provincial government and the Hibernia consortium (Hibernia Agreement). ${ }^{199}$ The provisions of the Hibernia Agreement specifically provided that it was not enacted pursuant to the Petroleum and Natural Gas $A c t^{200}$ or the Accord Acts. ${ }^{201}$ Similarly, the statutory royalty was not enacted pursuant to the Accord Acts. ${ }^{202}$ It has been suggested that the reason for specifically providing that the Accord Acts ${ }^{203}$ did not apply was because of questions as to whether such agreements could be authorized thereunder due to problems of administrative interdelegation and referential incorporation. ${ }^{204}$

\section{b. Cohasset}

The government of Nova Scotia entered into a specific royalty agreement for the Cohasset project in $1992 .{ }^{205}$ The Cohasset agreement provided incentives designed to be unique to the first offshore oil production project in Nova Scotia, including the granting of a high allowable rate of return on operating costs of 25 percent, and included the cost of abandonment as project costs. ${ }^{206}$ The Cohasset agreement provided for a fixed share royalty in the early years of the project and a relatively high net profit royalty later in the project, with gross royalties applying from the commencement of production. Changes to the project have required amendments to the original royalty agreement. ${ }^{207}$

\section{c. Sable}

The royalty regime for the Sable Offshore Energy Project (SOEP) is a negotiated regime which provides for gross royalties that increase solely on the basis of the lapse of time followed by a relatively high net revenue royalty once payout has been achieved.

The royalty regime for the SOEP was entered into between the government of Nova Scotia and the consortium of producers on 17 June 1999 (SOEP Agreement). ${ }^{208}$ The negotiations for the completion of the SOEP Agreement took over a year and a half. ${ }^{209}$ The SOEP Agreement was entered into under the authority of the Offshore Petroleum Royalty Act, ${ }^{210}$ which provides that the minister may enter into an agreement with each holder of a share in

Hibernia Development Project Royalty Agreement (1 September 1990) between Her Majesty The Queen in Right of the Province of Newfoundland, Mobil Oil Canada Properties, Chevron Canada Resources, PetroCanada Hibernia Partnership, Gulf Canada Resources, Mobil Oil Canada, Chevron Canada Resources and PetroCanada.

Supra note 181.

Supra note 3.

Ibid.

Ibid.

Supra note 101 at 188.

LASMO-Province of Nova Scotia Royalty Agreement for Cohasset/Panuke Project between Her Majesty the Queen in right of the Province of Nova Scotia represented by the Minister of Natural Resources and LASMO Nova Scotia Limited (1992).

Supra note 194 at 26.

Ibid.

Approved by the Governor in Council by O.I.C. 1999-338 (17 June 1999) (the SOEP Agreement). Supra note 101 at 195.

Supra note 182. 
a production licence pertaining to any matter in respect of which the Governor in Council may make regulations.

At the time of the entering into of the SOEP Agreement, production licences had not yet been granted, and therefore the SOEP Agreement was held in escrow until the production licences would be issued to the participants in the SOEP.

According to counsel for one of Canada's largest petroleum companies, ${ }^{211}$ the need to put the SOEP Agreement in escrow pending the granting of production licences indicated that the legislative regime did not adequately address the needs of producers to have royalty agreements in place in a timely manner. This meant that producers were left with the problem of having to manage the risk that the SOEP Agreement would not ultimately be binding on the government when taken out of escrow. ${ }^{212}$ The problems with the SOEP Agreement demonstrate the deficiencies in the Accord Acts regime because the provincial government is empowered by referential incorporation to make arrangements which will be binding on the federal government.

The federal Nova Scotia Accord $A c t^{213}$ provides:

99(3) Subject to this Act and the Regulations, the Offshore Petroleum Royalty Act and any regulations made thereunder apply, with such modifications as the circumstances require, for the purposes of this section and, without limiting the generality of the foregoing,

(a) a reference in that Act to Her Majesty in Right of the Province shall be deemed to be a reference to her Majesty in Right of Canada;

(b) reference in that Act to the Province of Nova Scotia or the Province of Nova Scotia lands shall be deemed to be reference to the offshore area; and

(c) a reference in that Act to the minister responsible for the administration of that Act shall be deemed to be a reference to the federal minister.

The Offshore Petroleum Royalty $A c t^{214}$ is incorporated by reference into the federal Nova Scotia Act. ${ }^{215}$ However, there is some doubt as to whether the referential incorporation is sufficient to enable the provincial government to enter into a separate agreement with the producers in relation to the offshore area. The federal Nova Scotia $A c t^{216}$ specifically provides that the regulations for the Offshore Petroleum Royalty $A c t^{217}$ are deemed to be part of the federal Nova Scotia Accord Act. Muscoby argues that if the SOEP Agreement was embodied in the regulations it would be binding immediately. However, he also points out that there is a risk of future amendments to regulations. ${ }^{218}$

Supra note 170.

Ibid.

Supra note 3.

Supra note 182.

Supra note 3.

Ibid.

Supra note 182.

Supra note 187 at 12. 


\section{OVERVIEW ON ATLANTIC NEGOTIATED REGIMES}

The negotiated royalty regimes established in both Newfoundland and Nova Scotia were able to provide special incentives for the green field exploration and development carried out in these areas. In Newfoundland, however, the gross royalty payable, which is a key element of the negotiated regime, had to be renegotiated within three years of the commencement of production for the Hibernia project. Moreover, the Nova Scotia agreements also had to be amended. Both regimes required a significant amount of time and effort for negotiations which arguably may have delayed the commencement of production. Furthermore, the federal and provincial legislative structure did not enable the provincial governments to enter easily into binding agreements with industry, which created further uncertainty. The problems associated with the negotiated regimes may be attributed to the fact that these were the first experiences of both Newfoundland and Nova Scotia with offshore oil royalties.

British Columbia can learn valuable lessons from the Newfoundland and Nova Scotia experiences with negotiated regimes. In particular, triggering events for increases in the gross royalties should be based on production and the depletion of reserves in addition to the lapse of time. Moreover, any accord legislation should have federal involvement in the agreement, or should specifically contemplate the ability of the provincial government to enter into a binding negotiated royalty agreement in case of an industry request.

\section{GENERIC ROYALTY REGIMES}

a. Introduction

In 1994, the government of Nova Scotia finalized the terms of a generic royalty regime set out in the Offshore Petroleum Royalty Regulations. ${ }^{219}$ On 13 June 1996, the Newfoundland Minister of Mines and Energy announced that Newfoundland would also be adapting a generic royalty regime to be implemented by amending the regulations to the Petroleum and Natural Gas Act. ${ }^{220}$ Newfoundland has yet to enact its regulations. However, according to a representative of the Department of Mines and Energy, ${ }^{221}$ the regulations will be enacted by the end of the summer of 2002 in order to accommodate the White Rose project.

Both the Nova Scotia and Newfoundland generic royalty regimes are based on the hybrid model used for the Alberta Cold Lake regime. The royalties are imposed on a project basis, wherein each project will be separately treated to the generic regime. The gross royalties will increase on the basis of specified thresholds.

\section{b. Operation of Generic Royalty Regimes}

Under the Newfoundland regime, the depletion of the resource and aggregate production amounts can trigger an imposition of an increased royalty. Increases in the royalty rate

221 Based on discussions held in May 2002. 
applicable under the gross royalty portion of the Nova Scotia generic regime is only triggered following the recovery by the producer of their costs.

Each component of the generic royalties is based on a specified royalty rate imposed on revenues earned following payout, in addition to a return allowance expressed as a fixed rate of return on the investment in excess of the long-term government bond rate. The net royalties are two-tiered, the second tier providing for an additional royalty imposed on extra profits, which are basically defined by formula as earnings in excess of certain return allowances. The top-tier royalties can be up to 30 percent in Newfoundland, and 35 percent in Nova Scotia. ${ }^{222}$

The Newfoundland generic regime will be applicable to the White Rose project. In discussions held with the representative of the Minister of Energy and Resources, we were informed that the regime was accepted by industry and that there will be no negotiation of special terms.

The Nova Scotia generic regime will be in place for the Marquis project. This project has not yet been approved by the Nova Scotia board. The Nova Scotia generic regime also contains special royalty structures for small oil and high risk areas. ${ }^{223}$ These are meant both to compensate producers for additional risk in certain areas, by reducing the amount of royalties payable, and to take into account the additional cost of recovery for small oil projects.

\section{c. Analysis of Generic Regimes}

Production has not yet commenced for the Marquis or White Rose projects, and therefore it is too early to tell how the generic regimes will hold up to changes in market conditions, exceptional costs or unexpected occurrences. The experience to date with the generic royalty regimes in both Newfoundland and Nova Scotia has been quite positive. Industry has accepted these regimes, and therefore the negotiation of royalties did not form part of the process for advancing the Marquis or the White Rose projects. In discussions held with a representative of the Newfoundland Department of Energy and Mines who corresponded with the representatives of the producers in relation to the White Rose project, we were informed that industry players were not overly concerned about the ability of the Newfoundland government to change the generic regime by amending the regulations. It was felt that the ability to change the regulations is not materially different from the ability of a federal or provincial government to amend an income tax statute. It was felt that it was preferable to have knowledge of the royalty regime from the outset of the project and not to have to enter into an uncertain negotiating process. 


\section{INTEGRATION OF THE ROYALTY REGIME INTO THE FEDERAL AND PROVINCIAL FISCAL REGIMES}

A royalty is an economic rent payable to the resource owner to compensate for depletion of the resource. Even where royalties are based on a notional income, royalties are separate from the imposition of income, sales and capital taxes on the corporations carrying out the development of the offshore petroleum reserves.

Federal and provincial taxes and duties are an additional cost of doing business in the British Columbia offshore area. Therefore, industry requires knowledge of the total amount of such costs in order to determine the potential profitability of the exploration and development. The legislative regime must provide certainty as to the application of the federal and provincial fiscal regimes to those producers operating in the British Columbia offshore area. Furthermore, the overall impact of the federal and provincial regimes should be examined and integrated so that there is no double imposition of tax or any distortion of incentive created by a mismatch of the royalty regime with the regime for income and other taxes. The legislation will have to set out clearly whether income earned in the British Columbia offshore area is to be treated as income earned in British Columbia and thereby is subject to the regime of federal and provincial income tax for British Columbia.

The regimes for Atlantic Canada provide that corporate income taxes are levied on income earned in the offshore areas as if such income were earned in the land portion of each province. ${ }^{224}$ Newfoundland has enacted the Offshore Area Corporate Income Tax Act, ${ }^{225}$ which essentially puts a ceiling on the amount of provincial income tax that will be imposed on corporations with permanent establishments in the Newfoundland offshore area.

Another issue which will have to be determined is whether royalties payable with respect to the British Columbia offshore oil production will be deductible against provincial income tax. Neither Newfoundland nor Nova Scotia permits the deduction of royalties payable to the provinces for the purposes of calculating income on which provincial income tax is imposed. Alberta, British Columbia and Saskatchewan provide for deductions of Crown charges.

The royalty regime must also take into account the federal income tax regime meant to encourage the development of petroleum resources and to tax such resources. Included in this regime are special investment tax credits for qualifying expenditures used in relation to the extraction of oil and gas. Investment tax credits reduce the ultimate cost to the producer of exploration and development, and the royalty regime should take into account investment tax credits in determining the threshold amounts and costs for the net profits.

Other income tax issues which arise are the application of capital tax and property taxes to the capital used by the producers in the British Columbia offshore area. In particular, the assessment acts should be amended to ensure that they do not permit a municipality to include in its rule the market value of the offshore facilities and offshore reserves. ${ }^{226}$ 
Capital taxes are imposed by provincial governments to tax the capital employed by a taxpayer. As offshore resource projects involve billions of dollars of capital, imposition of a capital tax could amount to an additional royalty. The royalty arrangements should either ensure that the offshore producers are exempt from capital tax or provide for a credit against royalties equal to the amount of capital taxes payable. The British Columbia government announced that the capital tax would be eliminated completely effective 1 September 2002. Successor governments, however, may decide to reimpose such tax. Thought must be given to ensuring there is no possibility for double taxation with respect to capital tax. Furthermore, it will have to be determined whether or not the supplies of taxable goods and services will be subject to the provincial and federal excise acts.

\section{CONCLUSION}

The east coast petroleum royalty regimes have been criticized for their uncertainty and complexity because of inconsistent references between the Accord Acts ${ }^{227}$ and provincial royalty legislation, and the questionable constitutionality of provincial royalty laws. Primarily through the careful drafting of the provincial royalty legislation, it will be possible for British Columbia to:

(a) eliminate inconsistent wording, definitional problems and unmatched ministerial powers between the provincial legislation and the B.C. Accord legislation; and

(b) set up with the federal government a royalty regime in which the federal-provincial jurisdictional issues are eliminated through proper incorporation by reference otherwise valid provincial royalty laws.

In so doing it may be possible to achieve a higher degree of certainty through a legislated royalty and to restrict royalty agreements to address special features of individual projects.

\section{F. SignifiCANT DISCOVERY DEFINITION}

The Accord Acts ${ }^{228}$ establish three classes of sequentially issued licences and set up a regime for the administration of those rights. Exploration licences grant the right to explore and the exclusive right to drill in an identified portion of the offshore area for a fixed nineyear period, after which the permit area reverts to the Crown. Significant discovery licences (SDLs) grant the holder an indefinite term to delineate and evaluate reserves. The Offshore Boards must issue an SDL when a discovery of hydrocarbons is indicated by flow testing and where the development and interpretation of geological and engineering factors suggest an accumulation of reservoirs of hydrocarbons having the potential for sustained future production. Production licences are issued for commercial discovery areas. They grant the holder the exclusive right to produce and obtain title to petroleum produced for an initial term of twenty-five years and for so long thereafter as production continues or the area remains capable of commercial production. 
The Supreme Court of Canada has held that, because of the significant effect of such a declaration on an applicant's investment, an applicant for an SDL will be entitled to procedural fairness and to the grant of a licence where reasonable grounds are proved; that is, the applicant must show reasonable grounds for believing that there is a possibility of sustained production and that there are reasonable grounds to believe that sustained production may be practicable.

In the Accord Acts, a "significant discovery" is defined:

"Significant discovery" means a discovery indicated by the first well on a geological feature that demonstrates by flow testing the existence of hydrocarbons in that feature and, having regard to geological and engineering factors, suggests the existence of an accumulation of hydrocarbons that has potential for sustained production. $^{229}$

Suppose that a well in deep water (over 6,000 feet deep) is being drilled. The equipment necessary to conduct flow testing in this deep water is so expensive that the explorers have decided not to have it on board for the initial well. If the well encounters hydrocarbons it will be sealed and the flow testing will take place when a second well is drilled. The Supreme Court of Canada interpreted "significant discovery" as follows:

The reference in s. 47 to the "first well" is obviously intended to mean the "first and only well" existing at the time of [significant discovery declaration] application. ${ }^{230}$

It is recommended that the definition of "significant discovery" be reconsidered to see if the technical references to flow testing continue to be useful. If this part of the test can be removed, an uncertainty which could well affect drilling operations could be removed.

Also, British Columbia and Canada may want to consider whether the Newfoundland Supreme Court's interpretation of "significant discovery" in a case dealing with PetroCanada's King's Cove well ${ }^{231}$ warrants revisiting the legislated definition. The King's Cove case held that applicants need not prove on a balance of probabilities a likelihood of sustained production, but need only establish that the information on their well suggests the possibility of sustained production.

Petro-Canada's King's Cove discovery well drill-stem test produced ten barrels of oil over a ten-hour period, though no oil was produced during the last two hours. Petro-Canada applied for a declaration of significant discovery. When the C-NOPB dismissed the application, Petro-Canada sought to quash the C-NOPB's decision. The Court found that the C-NOPB had imposed too stringent a burden of proof to determine whether the discovery was a significant discovery. The proper test, according to Barry J., is whether there are

2.3. Petro-Canada v. Canada-Newfoundland Offshore Petroleum Board (1995), 127 D.L.R. (4th) 483 (Nfld. S.C.) [King's Cove]. 
"reasonable grounds to believe there is a possibility of sustained production." 232 Justice Barry concluded:

Petro-Canada also had the legal burden of satisfying the Board by the data, hypotheses and theories presented, that Petro-Canada had met the standard of proof required by the legislation. The civil standard applies, that is proof on a preponderance of probabilities... The unusual situation, here, however, is that what must be so proved is merely data which "suggests" a "potential", that is a possibility. The result is that Petro-Canada had to prove the suggestion of a possibility on a balance of probabilities. ${ }^{233}$

The conversion of an exploration licence to an SDL, which follows on the declaration of a significant discovery, has important consequences. An exploration licence has a defined work requirement, a requirement to drill at least one well, and a fixed term. An SDL has no work commitment and no fixed term. The theory is that a truly significant discovery will entice its owners to evaluate that discovery with further work. It is true that the offshore boards have the right to order that a well be drilled on an SDL, but except for this recourse - which is draconian in its effect and so far has never been invoked - the land covered by the SDL is tied up forever.

British Columbia and Canada may wish to consider whether the courts have effectively altered the definition of "significant discovery" so that the only real requirement is that a well demonstrate by flow testing the existence of hydrocarbons. If they find that the second part of the test for significant discovery no longer has meaning because they find the judicially interpreted test too generous in light of the rights conferred by a significant discovery licence, they may wish to redefine "significant discovery" or impose a term or work requirement on the holder of an SDL.

\section{G. REGISTRY SYSTEM}

Each Offshore Board maintains a public registry of offshore rights. ${ }^{234} \mathrm{~A}$ registered interest generally takes priority over an unregistered interest. ${ }^{235}$ The registration system under the Accord Acts $^{236}$ is modelled after the registration scheme established in Alberta for Crown minerals under the Mines and Minerals Act. ${ }^{237}$ It allows for registration of ownership interests in licences and security interests in licences, but does not cover other types of common interests, such as options, farm-out earning rights, overriding royalty interests and net profits interests.

The current legislation allows only the following documents to be registered:

"interests," which are exploration licences, significant discovery licences and production licences ${ }^{238}$ (collectively "Licences"); and

Ibid. at 505 [emphasis added].

Newfoundland, supra note 3, s. 105; Nova Scotia, supra note 3, s. 108.

Newfoundland, ibid., s. 112; Nova Scotia, ibid., s. 115.

Supra note 3.

R.S.A. 2000, c. M-17.

Newfoundland, supra note 3, s. 47; Nova Scotia, supra note 3, s. 49. 
(b) "instruments," which are transfers of Licences or shares in Licences, notices of security interests granted in respect of Licences; assignments, postponements or discharges of security notices and discharges of operator liens.

The British Columbia and federal governments should consider expanding the scope of the British Columbia Offshore Registry to include royalties. Through a series of cases culminating with the Supreme Court of Canada's decision in Bank of Montreal v. Dynex Resources, ${ }^{239}$ it has become clear that royalties may be interests in land and registered as such in provincial land registries. As onshore oil and gas law now clearly recognizes a royalty as an interest capable of protection through registration, it would be appropriate for British Columbia and the federal government to consider expanding the definition of "interests" in any eventual Pacific Accord legislation to include royalties, and thereby permit royalties, or notices of royalties, to be registered with the Offshore Board.

Consideration should also be given to the registration of security interests in facilities and equipment other than ships ${ }^{240}$ located in the British Columbia offshore area. Either the Offshore Board Registry should be expanded, or British Columbia's personal property security legislation should be extended into the offshore to allow the registration of security interests. The latter may be the more efficient course, as lenders would be tempted to register under provincial general personal property security legislation in any event, and expanding the Offshore Board Registry may result in duplicate registrations.

\section{H. OTHER}

The $A c c o r d A c t^{21}$ regimes may be reconsidered and improved upon in a number of other areas, each of which are discussed below.

\section{ONSHORE TO OFFSHORE DRILLING}

Because of the proximity of British Columbia offshore petroleum resources to lands clearly within provincial jurisdiction, particularly in the vicinity of Graham Island, it is conceivable that wells will be directionally drilled from an onshore wellhead within the jurisdiction of the province to offshore reservoirs within federal jurisdiction. ${ }^{242}$

This is not a scenario that was contemplated when the Accord Acts ${ }^{243}$ regimes were established, but nevertheless, since 1995, four wells have been spudded in onshore Newfoundland for purposes of exploring offshore prospects. In each case, regulatory issues have been dealt with on an ad hoc basis, through intergovernmental administrative co-

2002 SCC 7.

Security on ships is governed by the Canada Shipping Act, supra note 31 .

Supra note 3.

The problem does not arise in the North Sea, where both offshore and onshore reserves are regulated by the central government. In the case of the Marladrum Field Reservoirs, which straddle the United Kingdom and the Netherlands, the matter is dealt with by intergovernmental agreement, with the operator complying with the more stringent of the two regulatory regimes. See Agreement between the United Kingdom of Great Britain and Northern Ireland and the Kingdom of the Netherlands, The Hague (May 1992).

Supra note 3. 
operation, with both the provincial Department of Mines and Energy and the C-NOPB issuing work authorizations. Although this approach has worked, it could become problematic if a commercial discovery was made, as it would not be clear, for example, what royalty regime would prevail.

The B.C. Oil and Gas Commission $\mathrm{Act}^{244}$ gives the commission the authority, subject to prior approval of the Lieutenant Governor in Council, to negotiate and enter into intergovernmental agreements with the Government of Canada and thereafter to administer such an agreement. Consequently, it should be possible in British Columbia to adopt the ad hoc approach described above. A better result, however, would be to deal with onshore-offshore directional drilling and the issues it raises in any eventual regulatory regime implemented pursuant to a Pacific Accord. ${ }^{245}$

\section{TREATMENT OF CONFIDENTIAL INFORMATION}

There are uncertainties respecting the disclosure by the Offshore Boards of confidential information which should be resolved, or at least reconsidered on policy grounds, in any eventual Pacific Accord.

The Offshore Boards receive technical data generated by operators and have a duty to keep this information confidential. This duty occasionally conflicts with their duty to others. Under the Accord Acts, for example, s. 119(2) of the Newfoundland Act, ${ }^{246}$ all information which is provided for the purposes of Part II (Petroleum Resources) or Part III (Petroleum Operations) is privileged and may not knowingly be disclosed by the Offshore Boards without the consent of the person who provided it. Section 119(5) permits the disclosure of certain types of information (such as well data and geographical data) after a period of time.

In the territories of Canada, the NEB takes the role of the offshore boards, and in Canadian Forest Oil v. Chevron Canada Resources Ranger Oil ${ }^{47}$ the NEB's duties to Chevron - which had applied for a declaration of commercial discovery and submitted confidential technical data to support its application - ran headlong into its duties to Canadian Forest which, as an adjacent licence-holder and a party affected by the NEB's decision, asked the NEB and then the Federal Court for the right to review Chevron's confidential technical data. The Federal Court decided that Chevron would be allowed to apply for an order of confidentiality under a separate proceeding. If it did not apply, then the NEB would release Chevron's information to Canadian Forest. The Court's decision favours the owner of the confidential information. The Pacific Accord should consider, perhaps more precisely than was possible two decades ago, the circumstances under which confidential information may be released to third parties.

245 For a more complete analysis of the issues, see A. Taylor \& J. Dickey, "Regulatory Regime: CanadaNewfoundland/Nova Scotia Offshore Petroleum Board Issues" (2001) 24 Dal. L.J. at 51. 
It may be argued that licence holders can employ other legislation, such as the federal Access to Information Act ${ }^{248}$ or the Privacy Act ${ }^{249}$ to forestall such disclosure. For example, s. 20(1) of the Access to Information Act prohibits the disclosure of trade secrets and confidential financial, commercial, scientific or technical information, as well as disclosure "which could reasonably be expected to result in material financial loss or gain to, or could reasonably be expected to prejudice the competitive position of, a third party." Although the Offshore Boards take the position that they are free to disclose information that is not privileged under s. 119(5), this should be clarified. ${ }^{250}$

\section{INCOMPLETE REGULATION OF DRAINAGE AND WASTE}

The current regulatory regimes under the Accord Acts ${ }^{251}$ do not provide a comprehensive regime for dealing with the legal issues associated with drainage and the correlative rights of persons interested in the same reservoir, resulting in a number of uncertainties as to how drainage issues will be resolved in offshore areas.

Each of the Offshore Boards has established an Oil and Gas Committee and has appointed a Chief Conservation Officer to hold inquiries, issue orders and give direction with regard to production and prevention of waste. Each of the existing $A c c o r d A c t s^{252}$ contain provisions to prevent waste. Additionally there are provisions for the voluntary and mandatory pooling within spacing units and for unitization of interests in production in pools which exceed the area of a spacing unit to prevent waste. There are no express provisions designed to address the protection of correlative rights. ${ }^{253}$ The Offshore Board's jurisdiction is based on its conservation mandate to prevent waste, rather than an equitable mandate to do justice between parties. Any eventual Pacific Accord legislation should follow provincial precedents in incorporating express provisions dealing with correlative rights.

\section{FINANCIAL RESPONSIBILITY REQUIREMENTS}

The Accord Acts ${ }^{254}$ impose a scheme of statutory liability and impose financial responsibility requirements entailing direct access for the regulators to post security, that is, absolute liability for actual loss or damage and spills to 30 million dollars and unlimited liability where fault or negligence and debris. These requirements effectively require operators to arrange letters of credit and indemnity bonds.

R.S.C. 1985 , c. A-1.

R.S.C. 1985, c. P-21.

For further discussion, see supra note 245.

Supra note 3.

Ibid.

Production in the Terra Nova field entails unitization, a process whereby parties holding licences for different geographies overlaying a common reservoir agree to consolidate their interests and to share project costs and revenues in relation to relative contribution of reserves, with periodic redetermination of the reserves attributable to various tracks within the field. 
Any eventual Pacific Accord legislation should recognize that offshore operators are all major companies with substantial assets, and that guarantees and undertakings should provide sufficient security without the need to tie up actual funds in escrow accounts. ${ }^{255}$

\section{CONCLuSION}

Jurisdictional, Aboriginal and environmental issues represent significant challenges to the establishment of a stable regulatory regime that will encourage industry to commit the vast amounts of capital required to develop British Columbia's offshore oil and gas resources. High levels of commitment and co-ordination from the federal and provincial governments will be required to overcome these obstacles.

Fortunately, Canada has consistently evolved innovative techniques for co-ordinating overlapping federal and provincial regulatory authorities and regulatory regimes in a workable and effective manner. The regimes on the east coast represent such a workable regulatory accommodation and should serve as the template for any eventual Pacific Accord.

The experience of working with the $A c c o r d A c t s^{256}$ for fifteen years, combined with a shift in philosophy to more result-oriented regulation, should open the door to useful changes in the British Columbia offshore oil and gas legal regime, changes which will encourage responsible activity, modernize regulation and, generally, increase benefits to residents of British Columbia and all of Canada from the timely development of British Columbia's west coast offshore oil and gas resources. 